\title{
Izzivi in potenciali uporabe alternativnih prihodnosti pokrajin v obdobju podnebnih sprememb: pregled literature in raziskava
}

Raziskava se osredotoča na možnost uporabe analize alternativnih prihodnosti in scenarijev pri krajinskem načrtovanju $\mathrm{v}$ obdobju podnebnih sprememb, kar bi zagotovilo širši pogled in poglobljeno razumevanje tega pristopa ter $s$ tem njegovo boljšo in učinkovitejšo uporabo $\mathrm{v}$ prihodnosti. Raziskava vključuje pregled literature in analizo praktičnih projektov, ki so se $\mathrm{v}$ zadnjih letih izvajali po svetu. Poleg tega je avtor med marcem in septembrom 2014 opravil elektronsko anketo, v kateri je preučeval vidike uporabe tega pristopa $\mathrm{v}$ povezavi $\mathrm{z}$ vplivi podnebnih sprememb. Anketiranci so bili izkušeni raziskovalci iz 18 držav, ki so od leta 2000 sodelovali pri vsaj enem praktičnem projektu, povezanem $s$ preučevano temo. Po analizi več kot 40 praktičnih projektov so bili v analizo vključeni tudi rezultati ankete, $s$ čimer je avtor dobil celostno sliko potencialov in omejitev analize alternativnih prihodnosti in scenarijev pri krajinskem načrtovanju s posebnim poudarkom na podnebnih spremembah. Izsledki potrjujejo, da ta metoda spada med najučinkovitejše pristope odločanja, ki se uporabljajo za sprejemanje krajinske politike na območjih, na katerih se pokrajina hitro spreminja pod pritiskom urbanizacije in podnebnih sprememb. Kljub temu obstaja vrzel med napredkom, ki ga ta pristop omogoča na različnih ravneh, in kompleksnostjo vzorcev, negotovosti in pretresov $\mathrm{v}$ pokrajini zaradi vplivov podnebnih sprememb v urbanizirajočem svetu. Raziskava kaže, da obravnavani pristop odločevalcem ponuja veliko priložnost, da razširijo svoj pogled in sprejmejo ustrezno krajinsko politiko, še preden $\mathrm{z}$ vidika trajnostnega razvoja dosežejo točko, $s$ katere ni več vrnitve. Pri uporabi analize alternativnih prihodnosti in scenarijev za zamišljanje pokrajin, na katere vplivajo podnebne spremembe in urbanizacija, naletimo tudi na določene težave in ovire, ki jih je treba odpraviti. Čeprav je raziskava bolj informativne narave, odpira nova vprašanja o tem pristopu in njegovi uporabi v prihodnosti in daje podlago nadaljnjim raziskavam.

Ključne besede: alternativne prihodnosti pokrajin, analiza scenarijev, podnebne spremembe, urbanizacija, anketa, stališča strokovnjakov 


\section{Uvod}

Svet postaja vse bolj urbaniziran (glej Mulligan in Crampton, 2005, ter Pimentel in Pimentel, 2006). Vse večje povpraševanje po prebivanju na urbanih območjih zaradi njihove družbenoekonomske privlačnosti (glej na primer Acharya in Barragán Codina, 2012; Cheng, 2012, ter Zhang idr., 2012) je v zadnjih letih povzročilo daljnosežne posledice za naravno pokrajino, kar je raziskovalce spodbudilo $\mathrm{k}$ razvijanju novih metod in tehnik merjenja, napovedovanju, prikazovanju in upravljanju sprememb pokrajinskih vzorcev in procesov (na primer Turner, 1989; Jenerette in Wu, 2001; Bender idr. 2005; Deng idr., 2008, ter Jenerette in Potere, 2010). Po letu 2000 se je v nekaterih ekoloških raziskavah poudarjal odnos med nenačrtnim širjenjem mest in izčrpavanjem naravnih virov po svetu (na primer Dale idr., 2000; Pickett idr., 2001; Jongman, 2002; Alberti in Marzluff, 2004; Kupfer, 2006; Ahern, 2007; Breuste idr, 2008; Mehaffy in Haas, 2012, in Obeng-Odoom, 2012). V skladu s temi razvojnimi smernicami so raziskovalci preučevali tudi vplive podnebnih sprememb na urbanizirana območja. Podnebne spremembe so kot eden najmočnejših povzročiteljev sprememb rabe in pokrovnosti tal pripeljale do močnih pretresov v urbaniziranih pokrajinah. Podatki kažejo, da so poplave, suše, nevihte in dviganje morske gladine glavne posledice podnebnih sprememb na urbanih območjih po vsem svetu (glej Hamin in Gurran, 2009). Pred kratkim so nekateri raziskovalci začeli iskati nove načine odkrivanja trajnostne rešitve za ta uničevalni pojav. Nekatere tovrstne raziskave kažejo, da je lahko oblikovanje domnev o morebitnih spremembah $\mathrm{v}$ pokrajini $s$ posebnim poudarkom na vplivih podnebnih sprememb in drugih pomembnih spremenljivkah ter nato zamišljanje teh sprememb v pokrajini zadosten način obveščanja odločevalcev o verjetnih vplivih posameznega niza krajinske politike na celotno pokrajino (na primer Bryan idr., 2008, ter Morley idr., 2012). Krajinska politika lahko obravnava podnebne spremembe, ki lahko povzročijo najrazličnejše spremembe $\mathrm{v}$ pokrajini. Zato $\mathrm{v}$ obdobju urbanizacije in podnebnih sprememb zamišljanje sprememb v pokrajini, ki so posledica urbanizacije in podnebnih sprememb, zagotavlja osnovo za informirane odločitve pri sprejemanju ustrezne krajinske politike. Ker vsak niz ukrepov s področja politike rabe in pokrovnosti tal povzroči določene spremembe $\mathrm{v}$ pokrajini, je jasno, da se stopnja ranljivosti in odpornosti pokrajine proti vplivom podnebnih sprememb od primera do primera razlikuje. Prikaz verjetnih učinkov teh politik na prihodnost pokrajine je lahko zato sestavni del blažilnih in prilagoditvenih strategij pri načrtovanju urbaniziranih pokrajin. Za sprejetje trajnostnih krajinskih politik za preprečevanje škodljivih vplivov podnebnih sprememb je treba preučiti in razumeti zakonitosti spreminjanja pokrajin skozi čas.
Vključevanje informacij o krajinski ekologiji v krajinsko načrtovanje je lahko ključno za reševanje problematike vplivov podnebnih sprememb na mesta z uporabo blažilnih in prilagoditvenih strategij (glej Opdam idr., 2009). S hkratnim obravnavanjem podnebnih sprememb, širjenjem mest in krajinske ekologije bi lahko rešili trenutne dileme v krajinskem načrtovanju. Kot odziv na urbane in regionalne izzive, ki jih povzročajo podnebne spremembe, avtor v raziskavi predlaga, naj se analiza alternativnih prihodnosti in scenarijev uporabi kot učinkovito orodje, ki bi omogočalo sprejemanje informiranih odločitev glede politike rabe in pokrovnosti tal. $\mathrm{Z}$ določanjem alternativnih prihodnosti pokrajin, ki so pod pritiskom vplivov podnebnih sprememb, lahko družbo obveščamo o tem, kaj nam lahko prinese prihodnost. $S$ tem pristopom lahko zagotovimo pravilno in zanesljivo krajinsko politiko, oblikovano na podlagi tehnoloških zmogljivosti, družbenih vrednot, ekološkega znanja in kolektivnega vedenja. Kljub temu še vedno obstaja veliko vprašanj glede uporabe tega pristopa za sprejemanje informiranih odločitev o medsebojnih povezavah med spremembami pokrajine, urbanizacijo in podnebnimi spremembami na podlagi predvidevanja različnih prihodnosti pokrajine. Avtor v raziskavi obravnava dve glavni vprašanji: 1 . je analiza alternativnih prihodnosti in scenarijev ustrezno in zanesljivo orodje za prikazovanje prihodnjih pokrajin in posledično sprejemanje politike krajinskega načrtovanja $\mathrm{v}$ obdobju podnebnih sprememb ter 2. kakšne so trenutne težave in potenciali, povezani $\mathrm{z}$ uporabo tega odločitvenega orodja $\mathrm{v}$ resničnem svetu.

\section{Metodologija}

V tej raziskavi se izraz »pokrajina « nanaša na splet različnih vrst človeške rabe tal in naravne pokrovnosti tal, ki skozi čas v velikem obsegu vplivajo druga na drugo. Avtor je v članku združil pregled mednarodne literature in informacije, ki so jih podali strokovnjaki na podlagi svojih praktičnih izkušenj, kar daje boljši vpogled $\mathrm{v}$ vlogo analize alternativnih prihodnosti in scenarijev pri ekološkem krajinskem načrtovanju z vidika podnebnih sprememb. V raziskavi je uporabil strategijo več pristopov. Glavni poudarek je na poglobljenem pregledu študij primerov iz različnih držav, $\mathrm{v}$ katerih je bil uporabljen pristop analize alternativnih prihodnosti in scenarijev. Avtor je študije primerov podrobno analiziral $z$ uporabo metode vsebinske analize, pregled pa je nato podkrepil z informativno anketo, ki jo je izvedel z majhno skupino izkušenih strokovnjakov z vsega sveta.

Za zbiranje potrebnih podatkov je uporabil različne vire informacij (glej Wang in Hofe, 2007, ter Deming in Swaffield, 2011). Najprej je zbral, izločil, razvrstil in pregledal velik nabor publikacij, vključno z najnovejšimi objavljenimi članki v recenziranih znanstvenih revijah, uglednih knjigah in tehnič- 
nih poročilih. Po pregledu mednarodne literature je z uporabo kompleksne opisne strategije izlušcil ključne pojme, na podlagi katerih je nato oblikoval informativni vprašalnik. E-vprašalnik s 24 vprašanji različne vrste je po elektronski pošti razposlal izbranim posameznikom, in sicer široki skupini potencialnih anketirancev, ki je vključevala univerzitetne učitelje ter strokovnjake s področja krajinske arhitekture, urbanističnega in regionalnega načrtovanja, ohranjanja biotske raznovrstnosti, pedologije, upravljanja habitatov, ekološkega kmetijstva, geologije, geografije, načrtovanja podeželja in obnove pokrajin.

Ena od prednosti vprašalnika je bila raznolikost vprašanj, saj so bila vanj na primer vključena vprašanja odprtega in zaprtega tipa, vprašanja, na katera so anketiranci odgovarjali z da ali ne, in vprašanja, pri katerih so morali anketiranci odgovore razvrstiti po izbrani lestvici. Vprašanja zaprtega tipa so bila oblikovana na podlagi Likertove lestvice, z njimi pa je avtor sistematično pridobil mnenja strokovnjakov o pomembnih zadevah. Za še podrobnejšo preučitev zadevne problematike je avtor uporabil tudi več vprašanj odprtega tipa, ki so razkrila stvari, ki jih z uporabo navadnih vprašanj z izbiro (ang. multiple-choice questions) običajno ni mogoče odkriti. Posameznike z ustreznimi akademskimi in strokovnimi izkušnjami za vključitev v anketo je avtor na podlagi ključnih besed poiskal v uveljavljenih znanstvenih podatkovnih zbirkah, kot je Science Direct. Tako je našel imena avtorjev, ki so svoje izsledke od konca 90. let 20. stoletja objavljali v recenziranih znanstvenih revijah. Avtor je na začetku vprašalnika postavil tudi posebno izločitveno vprašanje, da bi čim bolj izboljšal natančnost raziskave. Pri tem vprašanju je namreč anketirancem naročil, naj izpolnijo vprašalnik samo, če so od leta 2000 sodelovali pri vsaj enem praktičnem projektu $\mathrm{v}$ zvezi $\mathrm{z}$ alternativnimi prihodnostmi pokrajine. Poleg tega je zato, da bi se izognil izpadu vplivnih posameznikov s tega področja, uporabil pristop verižnega vzorčenja, $s$ katerim je poiskal dodatne pomembne osebe. Avtor je tako anketirance prosil, naj predlagajo ustrezne osebe, katerih delo in izkušnje bi bili pomembni za to raziskavo. $Z$ verižnim vzorčenjem je ugotovil spregledane pomembne osebe in razširil obseg raziskave. Tako je bilo na seznam anketirancev dodanih še več posameznikov.

Vprašalnike je izpolnilo 42 oseb iz 18 držav (preglednica 1). Med njimi jih je 31 odgovorilo na vsa vprašanja, 11 vprašalnikov pa ni bilo v celoti izpolnjenih. Nepopolno izpolnjeni vprašalniki so bili izključeni iz podrobne analize. Avtor se je tako osredotočil le na 31 pravilno izpolnjenih vprašalnikov, vendar je pri raziskavi upošteval tudi uporabne informacije iz nepopolno izpolnjenih vprašalnikov. Velikost vzorca se pri anketah običajno izračuna na podlagi formule, statističnih preglednic in povezav s podobnimi raziskavami ali kombinacije tovrstnih metod, pri anketi, pri kateri so anketiranci visoko usposobljeni in dobro obveščeni, pa zadostuje, da dosežemo točko zasičeno-
Preglednica 1: Geografska porazdelitev anketirancev

\begin{tabular}{|c|c|c|}
\hline regija & država & število \\
\hline \multirow{2}{*}{ Severna Amerika } & Kanada & 2 \\
\hline & ZDA & 10 \\
\hline \multirow{14}{*}{ Evropa } & Češka republika & 1 \\
\hline & Estonija & 1 \\
\hline & Finska & 2 \\
\hline & Francija & 3 \\
\hline & Nemčija & 3 \\
\hline & Italija & 4 \\
\hline & Latvija & 1 \\
\hline & Nizozemska & 2 \\
\hline & Slovaška & 1 \\
\hline & Slovenija & 1 \\
\hline & Španija & 1 \\
\hline & Švedska & 2 \\
\hline & Švica & 1 \\
\hline & Velika Britanija & 2 \\
\hline Oceanija & Avstralija & 4 \\
\hline Azija & Japonska & 1 \\
\hline
\end{tabular}

sti (glej Flick, 1998, ter Guest idr., 2006), na kateri raziskovalec ne opazi novih elementov v odgovorih. Poleg tega velja, da če se odgovori ponavljajo v pravilnem vzorcu, lahko to razumemo kot znak, da smo dosegli sprejemljivo raven napak pri vzorčenju. Po drugi strani pa je že geografska raznolikost vzorca zagotovila zanesljivost ankete. Poleg tega je bila pravilnost rezultatov ankete potencialno zajamčena tudi z raznolikostjo anketirancev, ki so prihajali z različnih znanstvenih področij. Vprašalniki so bili postopoma poslani ustreznim osebam, avtor pa je pri tem spremljal njihove odgovore. Potreboval je več kot šest mesecev, da je dosegel točko zasičenosti, na kateri ni bilo več treba povečevati velikosti vzorca.

Avtor je uporabne podatke predstavil $s$ statističnimi grafi in vsebinskimi slikami. Rezultati ankete so razkrili širok nabor skrbi in vprašanj, povezanih z uporabo alternativnih prihodnosti v krajinskem načrtovanju v zvezi s prihodnjimi podnebnimi spremembami. V splošnem je kombinacija ključnih pojmov, izpeljanih iz poglobljene analize uporabnih študij primera, in informacij, pridobljenih iz ankete, potencialno najpomembnejši dejavnik uporabe analize alternativnih prihodnosti in scenarijev v krajinskem načrtovanju v obdobju podnebnih sprememb.

\section{Predstavitev dosedanjih smeri razvoja}

Analiza alternativnih prihodnosti in scenarijev je pristop, ki omogoča sprejemanje informiranih odločitev glede mogočih 
prihodnosti. Kot ugotavlja Remi Barre (2004: 116, navedeno v Kosow in Gabner, 2008), » nam scenariji omogočajo, da gledamo daleč naokrog «. V veliko primerih » podpirajo dolgoročnejša in bolj sistemsko usmerjena opazovanja kot drugi pristopi (Kosow in Gabner, 2008: 19). Sandra Greeuw idr. (2000: 7) poudarjajo, da je »ta pristop morda najučinkovitejši, če ga razumemo kot močno orodje za širjenje pogledov, odpiranje vprašanj in zoperstavljanje tradicionalni modrosti «. Pri obravnavi uporabe analize alternativnih prihodnosti in scenarijev $\mathrm{v}$ novejši zgodovini krajinskega načrtovanja je treba upoštevati različne spremenljivke in dejavnike. $V$ splošnem se je $\mathrm{v}$ akademskem svetu analiza alternativnih prihodnosti in scenarijev pojavila v raziskavi Williama F. Ogburna, v kateri se je ta osredotočal na družbene trende in njihove posledice v ZDA med letoma 1930 in 1933 (Odum, 1951). V 50. in 60. letih 20. stoletja se je ta pristop uporabljal pri poslovnem upravljanju in trženju. Še en primer prizadevanja za uporabo analize alternativnih prihodnosti in scenarijev v 20. stoletju je bila knjiga z naslovom The Limits to Growth (Meadows idr., 1972, ki je predstavila računalniško podprto simulacijo rezultatov interakcij med okoljskim in človeškim sistemom. Kot glavne spremenljivke, na podlagi katerih so oblikovali eksponentni model, so avtorji upoštevali svetovno prebivalstvo, onesnaženje, industrializacijo, izčrpanje virov in proizvodnjo hrane. Kljub temu pa je bila uporaba alternativnih prihodnosti v krajinskem načrtovanju odvisna od zahtev in tehnoloških orodij, ki so se razvila šele pozneje, $v$ treh desetletjih po 60 . letih 20 . stoletja.

Skupaj z iznajdbo primitivnih računalnikov so v 60. letih prejšnjega stoletja v krajinskem načrtovanju razvili tudi kvantitativne tehnike (Fabos, 1985). To je pomenilo kvantni preskok $\mathrm{k}$ zamišljanju pokrajin $\mathrm{v}$ poznejših desetletjih. $\mathrm{V}$ skladu $\mathrm{s}$ tem razvojem je Roger Tomlinson (1968) v Kanadi predstavil prvi geografski informacijski sistem (GIS). Čez leto dni je Ian McHarg napisal knjigo z naslovom Design with Nature, v kateri je zagovarjal uporabo ekološkega znanja pri krajinskem načrtovanju. McHarg (1969) je predlagal presejalno tehniko za analizo odnosa med različnimi plastmi pokrajine, od popolnoma naravnih do človeških dejavnikov. V 70. letih 20. stoletja so GIS razvili mnogi raziskovalci po svetu. Preboji na področju nelinearnih sistemov, fraktalov in teorije kaosa so se začeli pojavljati v 80. letih in pripeljali do pomembnega napredka $\mathrm{v}$ urbanističnem modeliranju (Liu, 2009: 16) in simulaciji pokrajin. Od takrat se za modeliranje rasti mest in sprememb $\mathrm{v}$ pokrajini uporabljajo celični avtomati (CA) kot učinkovita tehnika simulacije pokrajin. Ti napredki so utrli pot uporabi alternativnih prihodnosti v krajinskem načrtovanju. Sočasno $s$ temi trendi se je pojavil tudi pojem »podnebne spremembe «, ki ga je prvi uporabil geokemik Wallace Broecker (1975). To je pripeljalo do opredelitve nove veje znanja o podnebnih spremembah in krajinskem načrtovanju. Za tem je bilo izdanih več temeljnih del, ki so z različnih vidikov povezala širjenje mest in krajinsko načrtovanje s podnebnimi spremembami (na primer Crichton idr., 2009; Condon idr., 2009; Hodson in Marvin, 2010; Wilson in Piper, 2010; Calthorpe, 2011; Rosenzweig idr., 2011; Watson in Adams, 2011; Cartwright idr., 2012; Moser in Boykoff, 2013; Lee, 2014, ter Prutsch idr., 2014). Analiza alternativnih prihodnosti in scenarijev se je v krajinskem načrtovanju začela uporabljati v 90. letih 20. stoletja (Botequilha Leitão in Ahern, 2002), in sicer na Nizozemskem (Harms idr., 1993, in Schooenboom, 1995) in v ZDA (Landis, 1995; Steinitz idr., 1996; Freemark idr., 1996; Hulse idr., 1997; Ahern, 1997; White idr., 1997, in Ahern, 1999). Pristop se je nato pogosto uporabljal v ZDA (na primer Hulse idr., 2000; Theobold in Hobbs, 2002; Hunter idr., 2003; Steinitz idr., 2003; Aycrigg idr., 2004; Berger in Bolte, 2004; Hulse idr., 2004; Nassauer in Corry, 2004; Reyes idr., 2004; Santlemann idr., 2004; Schumaker idr., 2004; Corry in Nassauer, 2005; Kepner idr., 2008; Hulse idr., 2009; Sleeter idr., 2012, in Penteado, 2013), Avstraliji in Evropi (na primer Patel idr., 2007; Bryan idr., 2008; Soliva idr., 2008; Verburg idr., 2010; Oana idr., 2011, ter Morley idr., 2012), Aziji (na primer Wang, 2011; Sun idr., 2012; Pan idr., 2014, ter Shoyama in Yamagata, 2014) in celo v državah v razvoju (na primer Ferraz idr., 2005; Bao Le idr., 2010, ter Sheikh-Goodarzi idr., 2012).

Analiza alternativnih prihodnosti in scenarijev velja za pomemben prispevek h krajinskim raziskavam. Elen Deming in Simon Swaffield (2011: 111) jo na primer opredeljujeta kot » posebno vrsto uporabe dinamičnega simulacijskega modeliranja za izboljšanje razumevanja posledic različnih političnih odločitev za pokrajino «. Pri uporabi alternativnih prihodnosti pri krajinskem načrtovanju gre za večnamenski pristop $k$ reševanju širokega spektra vprašanj, povezanih s pokrajino. Večina jih je posredno ali neposredno povezana s podnebnimi spremembami. Pregled novejših raziskav kaže, da raziskovalci preučujejo merila ali kazalnike, s katerimi se merijo podnebne spremembe. David Theobald in Thompson Hobbs (2002) sta na primer preučevala pomen varovanja biotske raznovrstnosti na zasebnih zemljiščih na območju Lower Blue Basin v Koloradu, pri čemer dosledno poudarjata odločilno vlogo déležnikov. V neki drugi raziskavi so Carl Steinitz idr. (2003) posebno pozornost namenili vodi in biotski raznovrstnosti v zgornji dolini reke San Pedro, pri čemer so ugotovili, da urbanizacija in kmetijske dejavnosti najbolj obremenjujejo okolje na tem območju. Glavno merilo pri tej raziskavi je bila biotska raznovrstnost. V nekaterih primerih (na primer Hunter idr., 2003) so bile alternativne prihodnosti uporabljene za določitev razmerja med demografskim gibanjem in z njim povezanimi spremembami v rabi tal. Raziskovalci so še zlasti preučevali vpliv sprememb v rabi tal na naravne habitate. Lori Hunter idr. (2003) so pri preučevanju kalifornijske puščave Mojave ugotovili, da imajo puščave krhko ekologijo in da so zato bolj podvržene človeškim obremenitvam. Ugotovili so, da bi lahko z gosto gradnjo na teh 
območjih zmanjšali človekove posege v naravo za več kot 80 \% ter tako zagotovili življenjski prostor ogroženim rastlinskim in živalskim vrstam. Joan Nassauer in Robert Corry (2004) sta v svoji raziskavi predstavila uporabo normativnih scenarijev na področju krajinske ekologije $\mathrm{v}$ kmetijskih porečjih v Iowi, pri čemer sta uporabila tri scenarije: proizvodnjo, kakovost vode in biotsko raznovrstnost. David Hulse idr. (2004) so uporabili alternativne prihodnosti pokrajine v dolini reke Willamette, da bi preučili verjetne vplive različnih politik rabe zemljišč in vode na prihodnost pokrajine. Gre za primer uporabe alternativnih prihodnosti v krajinskem načrtovanju zaradi raznolikosti in števila udeležencev v procesu oblikovanja domnev ter precejšnjega števila vrst pokrovnosti tal, opredeljenih za zemljevide. Poleg tega so avtorji v raziskavi izdelali karto ohranitvenih in obnovitvenih priložnosti za uporabo pri ohranitvenem scenariju, ki kaže, da so vprašanja, povezana s podnebnimi spremembami, med raziskovalci zelo aktualna.

Robert Lilieholm idr. (2005) so preučevali odnos med šijenjem mest ter varstvom okoljske kakovosti in javnega zdravja $\mathrm{v}$ ameriški zvezni državi Utah, da bi določili nasprotja, ki se lahko sčasoma pojavijo med temi spremenljivkami. $\mathrm{V}$ raziskavi, katere glavni poudarek je bil na kakovosti življenja, so avtorji predstavili okvir za predvidevanje verjetnih vplivov širjenja mest na okoljske razmere. Tara Sharma idr. (2005) so se osredotočili na pojem trajnostnosti pri uporabi alternativnih prihodnosti na območju povodja Georgia (ang. Georgia Basin) v kanadski provinci Britanska Kolumbija. Ugotovili so, da je glavna prednost uporabe alternativnih prihodnosti pri krajinskem načrtovanju ta, da lahko na podlagi tega pristopa déležniki sprejemajo informirane odločitve in politiko $s$ področja rabe tal v smeri trajnostne prihodnosti. V svoji družbeno-okoljski raziskavi so David Mouat idr. (2006) preučevali razmerje med širjenjem puščave in revšcino $\mathrm{z}$ uporabo alternativnih prihodnosti. William Kepner idr. (2008) so raziskovali potencialne težave $s$ kakovostjo vode kot posledico sprememb v pokrovnosti tal na zahodu Severne Amerike med Tihim oceanom in Skalnim gorovjem, da bi določili uporabne možnosti za trajnostno upravljanje naravnih virov.

Pregled literature kaže, da so se vse raziskave alternativnih prihodnosti osredotočale na pojem kolektivne modrosti v krajinskem načrtovanju. Joan Baker idr. (2004) menijo, da pri sprejemanju odločitev znotraj posamezne skupnosti običajno sodelujejo déležniki z zelo različnimi stališči in vrednotami. Najpomembnejši končni proizvod tega procesa je oblikovanje soglasja ali kompromisa o zaželenih ciljih in prednostnih nalogah oziroma skupne vizije prihodnosti. Namen analize alternativnih prihodnosti je olajšati ta proces oblikovanja soglasja. Mouat idr. (2006) ugotavljajo, da je analiza alternativnih prihodnosti forum za izmenjavo skrbi, vprašanj in upov, povezanih s prihodnostjo.
Na podlagi preučitve prednosti uporabe alternativnih prihodnosti v krajinskem načrtovanju v več kot dvajsetletnem obdobju lahko ta pristop uporabimo tudi pri zamišljanju pokrajin v povezavi z verjetnimi vplivi podnebnih sprememb. Uporaba analize alternativnih prihodnosti in scenarijev za zamišljanje krajinskih politik $\mathrm{v}$ povezavi z vplivi podnebnih sprememb se je v zadnjem desetletju povečala. V Avstraliji sta bili opravljeni obsežni raziskavi alternativnih prihodnosti pokrajin - na območju spodnjega toka reke Murray (Bryan idr., 2008) in v Novem Južnem Walesu (Morley idr., 2012) -, ki jasno kažeta, da so podnebne spremembe in njihovi vplivi na pokrajino postali najpomembnejšs vprašanje, $s$ katerim se ukvarjajo raziskovalci, oblasti in oblikovalci politike. Brett Bryan idr. (2008) so preučevali sušna območja in se osredotočili na podnebne spremembe kot dejavnik, ki najbolj vpliva na pokrajine. Philip Morley idr. (2012) so raziskovali alternativne prihodnosti pokrajine in prilagoditev na podnebne spremembe, da bi pokazali, da je lahko analiza alternativnih prihodnosti in scenarijev močno orodje za predvidevanje vplivov podnebnih sprememb na obalna naselja in skupnosti. $V$ drugi avstralski raziskavi alternativnih prihodnosti (Meyer idr., 2013) so avtorji obravnavali pomen preučevanja proizvodnje in varstva hrane v obdobju podnebnih sprememb. Raziskava je druge raziskovalce spodbudila $\mathrm{k}$ preučevanju trenutnih vrzeli in težav pri uporabi tega pristopa. Podoben trend lahko opazimo pri evropskih raziskavah. $V$ britanski raziskavi naravnega rezervata Humberhead Levels so Trudie Dockerty idr. (2006) predstavili pristop k oblikovanju scenarijev, ki lahko vključujejo potencialne vplive podnebnih sprememb in izražajo negotovost napovedi podnebnih sprememb zaradi različnih okoljskih politik. Peter Verburg idr. (2010) ugotavljajo, da na spremembe v rabi tal v Evropi vplivajo najrazličnejši lokalni pogoji in globalni procesi. Podnebne spremembe so upoštevali kot pomemben dejavnik, ki vpliva na te spremenljivke. Poleg tega obstaja še več dokazov o tem, da je uporaba alternativnih prihodnosti v povezavi s podnebnimi spremembami s posebnim poudarkom na prostorsko eksplicitnih pokrajinskih vzorcih prepoznana kot prioriteta in nuja na področju krajinskega načrtovanja. Kljub vsem zgoraj omenjenim raziskavam pa ostaja še veliko vprašanj, na katera bo treba odgovoriti. V nadaljevanju so obravnavani nekateri pomembni izzivi, vrzeli in potenciali, povezani z uporabo analize alternativnih prihodnosti in scenarijev $\mathrm{v}$ krajinskem načrtovanju $\mathrm{v}$ povezavi s podnebnimi spremembami.

\section{Rezultati in razprava}

Uporaba analize alternativnih prihodnosti in scenarijev je pristop, ki se vse bolj uveljavlja za preučevanje verjetnih vplivov podnebnih sprememb na urbanizirajoče pokrajine. Od 90. let 20. stoletja je bilo o tej analizi opravljenih že veliko raziskav po vsem svetu, še zlasti v razvitih državah. Čeprav se večina raziskav v praksi med seboj razlikuje, je bil pri vseh projektih 
uporabljen podoben mehanizem. $\mathrm{V}$ tej raziskavi je ta mehanizem sestavljen iz štirih delov: opredelitve, prikaza, ocenjevanja in sinteze (preglednica 2). $\mathrm{V}$ naslednjem poglavju so povzeti rezultati raziskave, ki obsegajo najrazličnejše ugotovitve izčrpnega pregleda mednarodne literature, analize praktičnih projektov in ankete. Za boljšo razumljivost in funkcionalnost so rezultati analize podatkov in pregleda literature predstavljeni kar se da opisno.

\subsection{Opredelitev 4.1.1 Zbiranje podatkov}

$\mathrm{Za}$ zbiranje različnih vrst podatkov, vključno s podatki iz ustnih virov in okoljskimi podatki, je treba uporabiti različne metode in orodja. Treba je upoštevati vse mogoče podatke, od navadnih podatkov o demografskih gibanjih, spremembah cen zemljǐšć, povpraševanju po stanovanjih, bivalnih vzorcih in porabi vode do bolj specifičnih podatkov, povezanih s podnebnimi spremembami, kot so stopnja priseljevanja kot posledica podnebnih sprememb, povpraševanje po energiji, varnost hrane, spremembe količine dežja in temperaturnih vzorcev ter količina emisij toplogrednih plinov. Pri tem procesu je pomembno, da stalno prekrivamo podatke iz ustnih virov in okoljske podatke, saj tako zagotovimo, da je njihova natančnost na sprejemljivi ravni. V primeru podatkov iz ustnih virov je prav tako pomembno, da opredelimo primeren okvir sodelovanja déležnikov pri odločanju. Déležniki so družbene sile, ki jih lahko razdelimo v štiri glavne skupine, in sicer na laike, vplivne osebe, strokovnjake in lokalne oblasti. Za dosego soglasja glede preučevanih vprašanj v tako veliki skupini déležnikov je treba oblikovati celostni načrt, $s$ katerim zagotovimo aktivno in učinkovito vlogo vsake skupine $\mathrm{v}$ celotnem procesu. Izkušnje iz prejšnjih projektov s področja krajinskega načrtovanja kažejo, da se raziskovalci med zbiranjem podatkov stalno soočajo s težavami (na primer Hulse idr., 2004, ter Sheikh-Goodarzi idr., 2012). Posvečanje posebne pozornosti vplivom podnebnih sprememb pa lahko položaj še poslabša, saj podatki, povezani s podnebnimi spremembami, niso povsod na voljo. Poleg tega je zbiranje ustreznih podatkov pogosto dolgotrajno in drago, saj se morajo raziskovalci zanašati na tehnološka orodja, kot so satelitski posnetki, vidni in številski podatki ter tehnične karte. Tudi metode, s katerimi se zbirajo natančni podatki, so izjemno raznolike in kompleksne. Položaj se še poslabša, kadar morajo raziskovalci zbirati podatke na podlagi terenskih meritev.

Druga težava je natančnost podatkov. Za čim večjo natančnost je treba vzporedno uporabljati različne metode zbiranja podatkov. Daljinsko zaznavanje ne sme biti edina metoda zbiranja podatkov o pokrajini, povezanih s podnebnimi spremembami, čeprav se včasih izkaže za učinkovito. $V$ nekaterih primerih je treba to dopolniti z neposrednim opazovanjem in teren- skimi meritvami. Zbiranje podatkov je izjemno pomembno, saj bosta simulacija pokrajine in oblikovanje domnev temeljila na nizu podatkov, zbranih z različnimi metodami in iz različnih virov. Morley idr. (2012) so navedli številne težave pri zbiranju podatkov, vključno $\mathrm{z}$ dostopnostjo podatkov, časom, ki je bil na voljo za zbiranje, in slabo kakovostjo podatkov. Poleg tega bogat niz pravilnih podatkov ponuja priložnost za dolgoročen prikaz pokrajine, na primer $\mathrm{v}$ obnovitvenih in sanacijskih projektih. Biološko-geološko-podnebne karte (glej Bell, 1999), vključno $s$ kartami vseh zgodovinskih vrst rabe in pokrovnosti tal, so bistvene za razumevanje preteklih razmer v pokrajini in njenih ekoloških potreb. Tovrstne karte vsebujejo najrazličnejše prostorske podatke o pokrajini ter so zanesljiva podlaga za primerjavo in analizo pokrajine $\mathrm{v}$ preteklosti, sedanjosti in prihodnosti.

\subsubsection{Oblikovanje domnev}

Mouat idr. (2006) ugotavljajo, da je analiza alternativnih prihodnosti in scenarijev v krajinskem nacrrtovanju forum za izmenjavo skrbi, vprašanj in upov, povezanih s prihodnostjo. Vsebina domnev so pravila, po katerih se pokrajina sčasoma spreminja. Preobrazba pokrajine bi morala biti logično formulirana in kodirana, sčimer bi se oblikoval niz pravil o spreminjanju pokrajine. Pravila so močno odvisna od najrazličnejših spremenljivk, ki jih lahko razdelimo $\mathrm{v}$ abiotske, biotske in kulturne vire (glej Botequilha Leitão, 2006). Inherentna kompleksnost naravnih ekosistemov na eni strani ter raznolikost in negotovost človeških dejavnosti v pokrajini na drugi ustvarjajo zapletene pogoje za oblikovanje utemeljenih in verjetnih domnev. Če raziskovalci posvečajo več pozornosti vplivom podnebnih sprememb, postane oblikovanje domnev zapletenejše zaradi pojava novih spremenljivk in negotovosti. Čeprav so podnebne spremembe modni izraz, jim lokalne oblasti še vedno ne posvečajo dovolj pozornosti. Prav tako ne gre za pojav, ki bi bil splošno znan med laiki. Zato je le malo verjetno, da bi se brez ustreznih predhodnih izobraževalnih programov lahko oblikovale utemeljene in verjetne domneve glede alternativnih prihodnosti, povezanih s podnebnimi spremembami.

Projekt alternativnih prihodnosti pokrajine zahteva dva niza domnev (slika 1). Najprej se oblikuje niz splošnih domnev za vse scenarije na podlagi splošnih pogojev v preučevani pokrajini, nato pa je treba oblikovati specifične domneve za vsako posamezno alternativno prihodnost glede na specifične pogoje. Oblikovanje specifičnih domnev je težka naloga, saj zahteva različne vrste znanja.

Doseganje splošnega dogovora je nepogrešljivo za oblikovanje utemeljenih in verjetnih domnev ter lahko pripelje do pozitivnega soglasja glede odločitvenih vprašanj. Tako soglasje je trdna podlaga naslednjim korakom zadevnega procesa. Za čim 


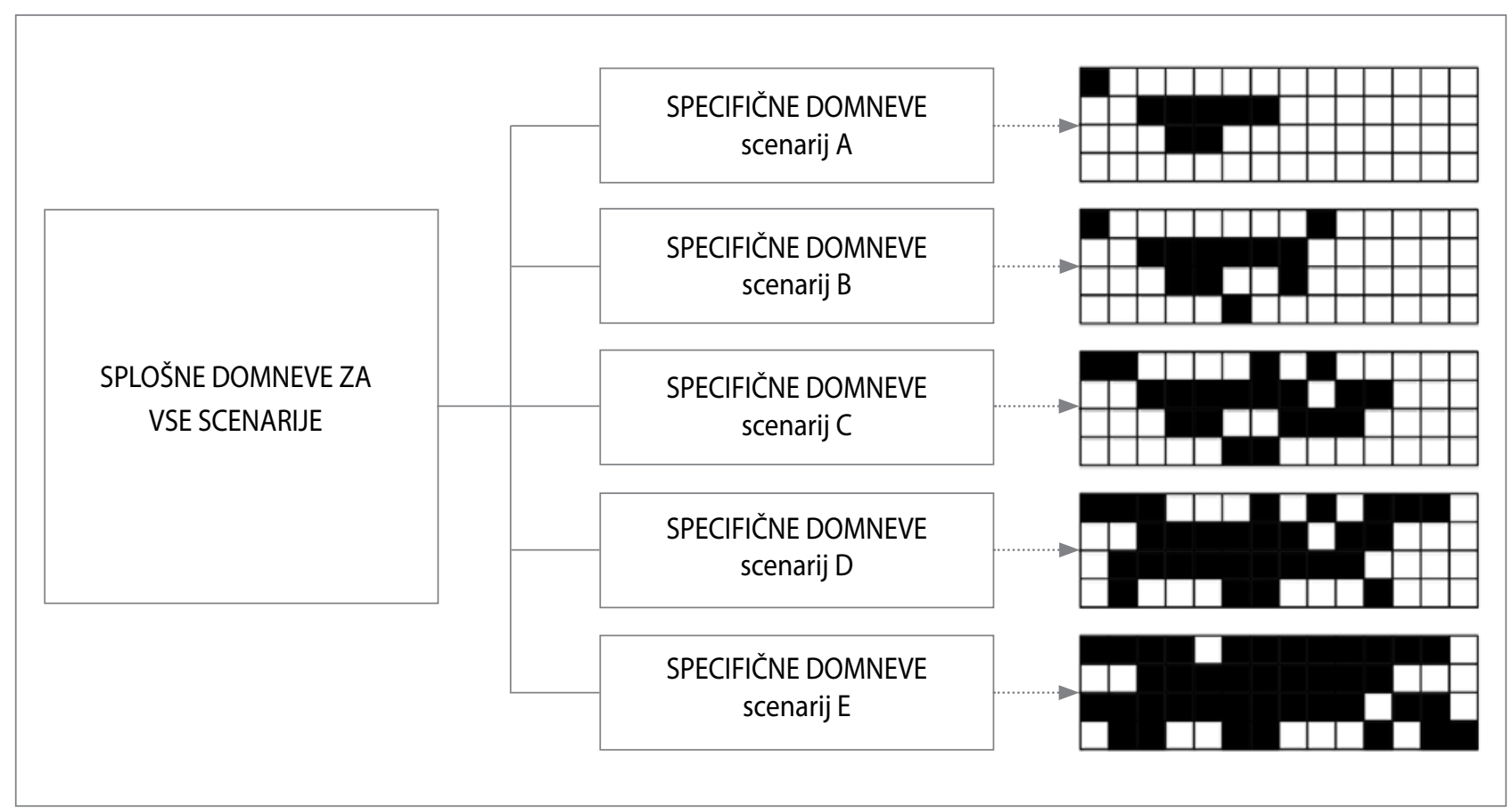

Slika 1: Oblikovanje splošnih in specifičnih domnev za izgradnjo alternativnih prihodnosti

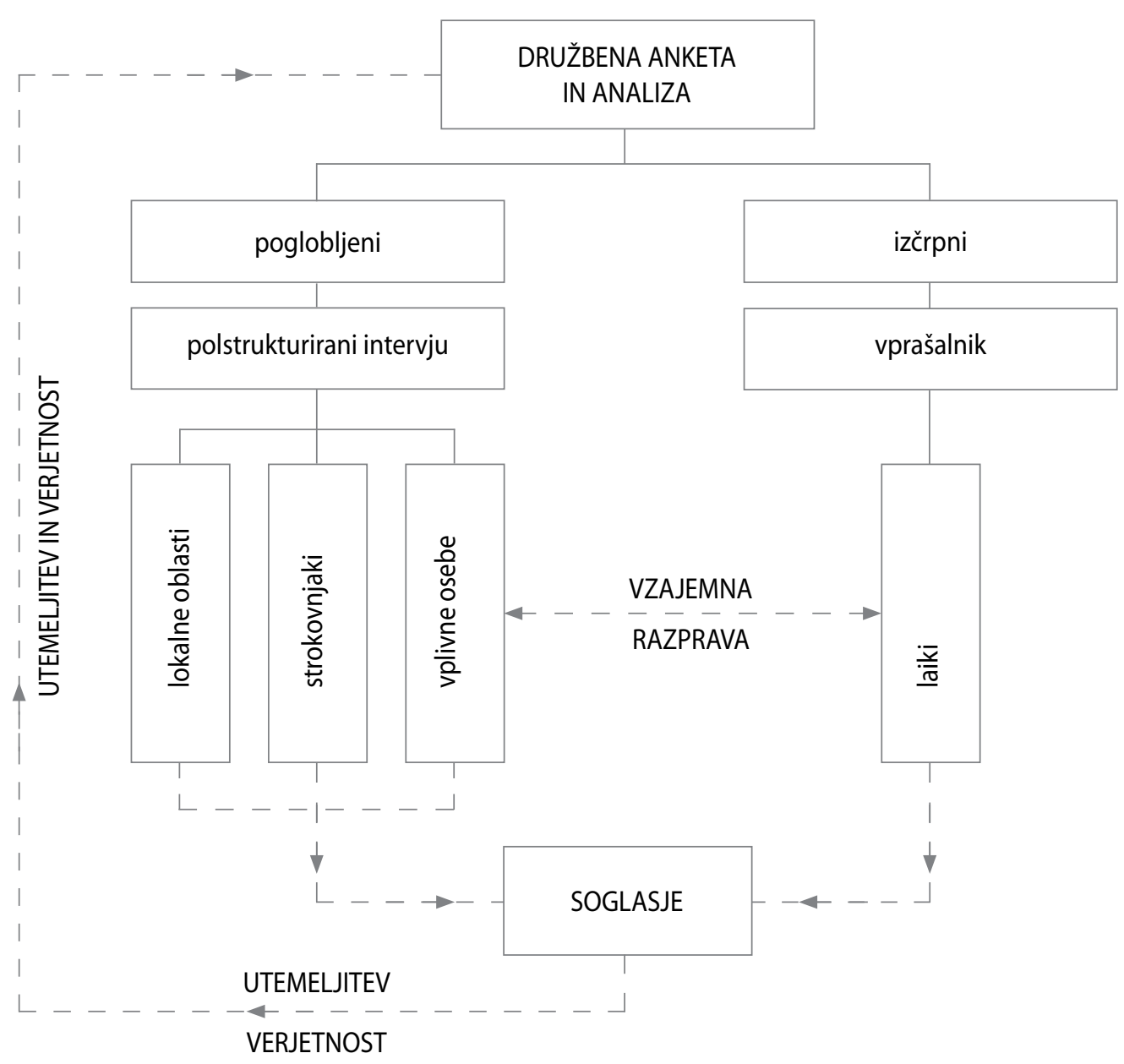

Slika 2: Predlagani model doseganja splošnega soglasja o domnevah med različnimi déležniki 


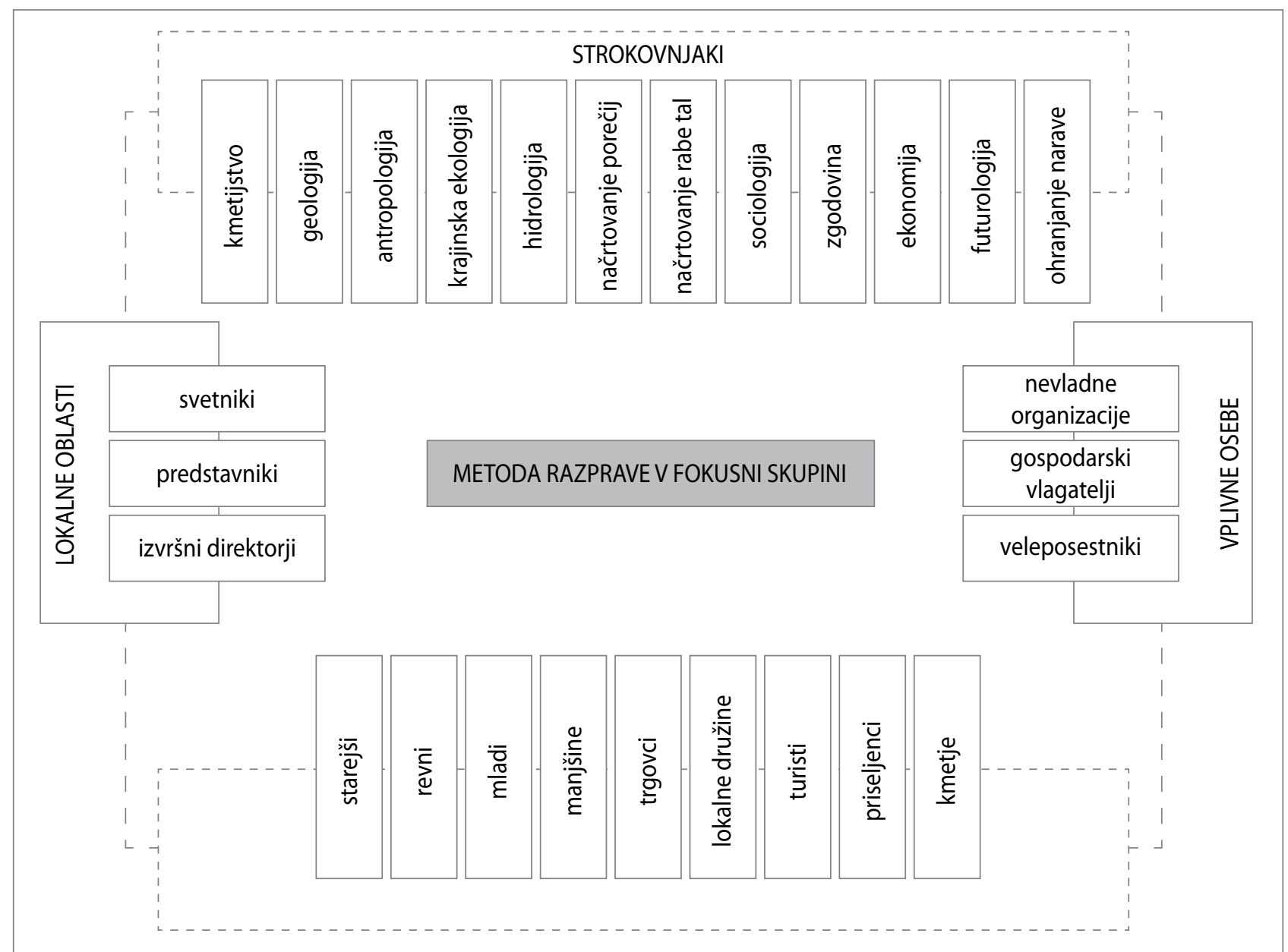

Slika 3: Predlagani model organizacije razprave v fokusni skupini med strokovnjaki, vplivnimi osebami, lokalnimi oblastmi in laiki

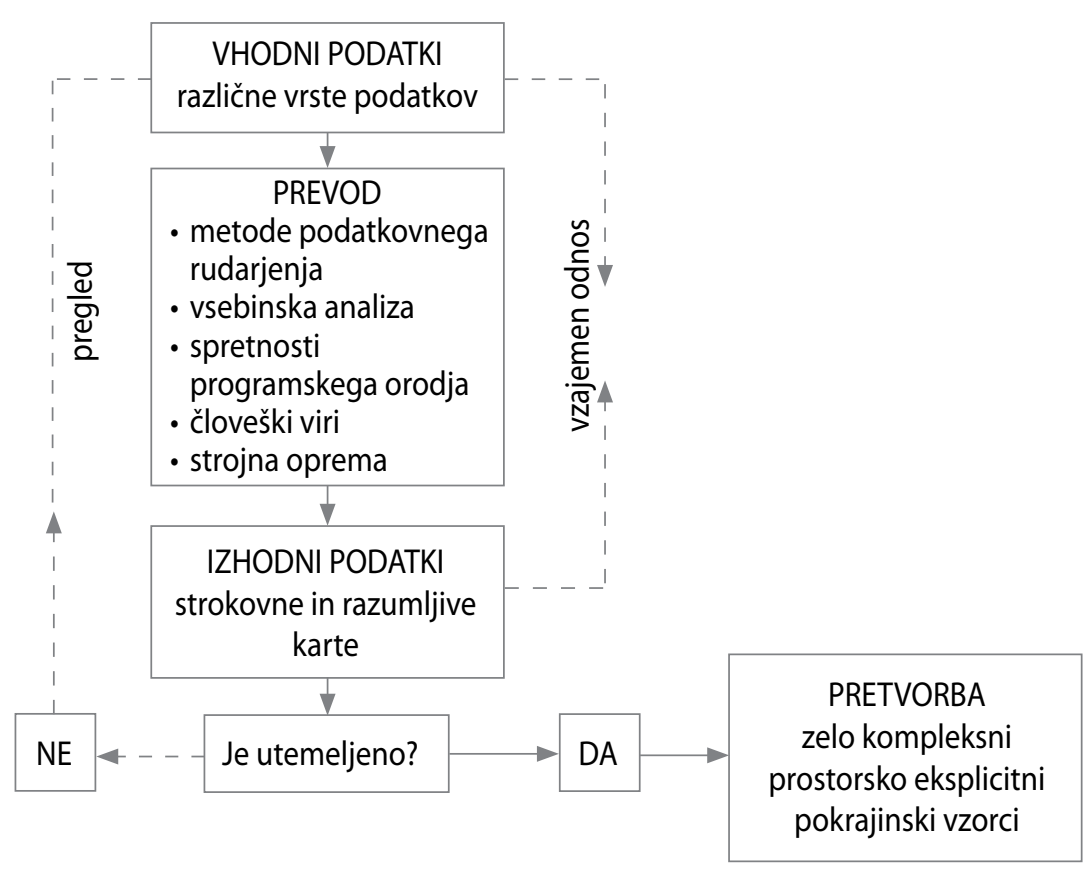

Slika 4: Poenostavljen proces pretvorbe podatkov iz ustnih virov ter okoljskih in pisnih podatkov v prostorsko eksplicitne pokrajinske vzorce na podlagi domnev 


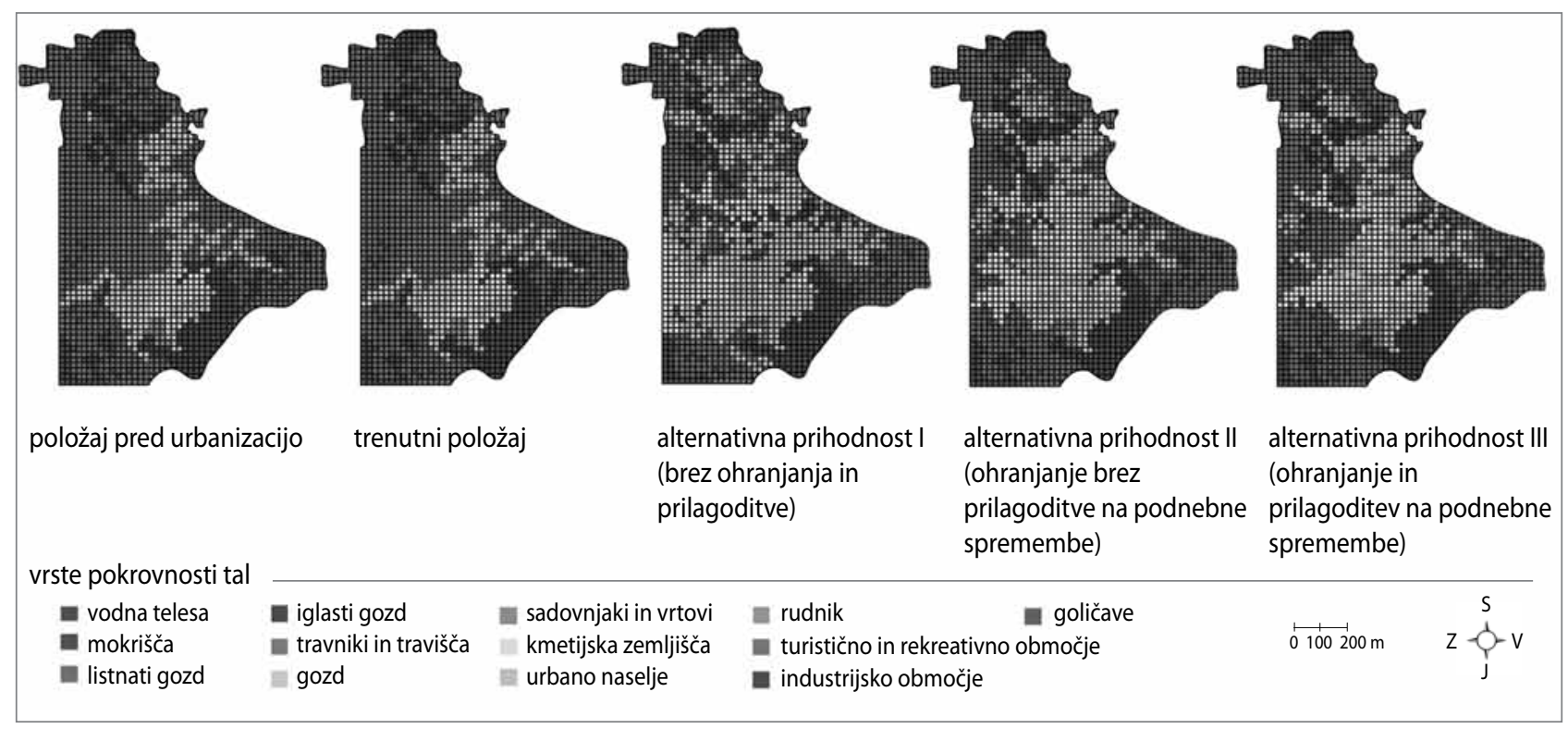

Slika 5: Običajen prikaz trenutnega položaja in položaja pred urbanizacijo ter treh alternativnih prihodnosti (»brez ohranjanja in prilagoditve», »ohranjanje brez prilagoditve na podnebne spremembe« in »ohranjanje in prilagoditev na podnebne spremembe«) v simulirani pokrajini

večjo natančnost domnev je bistveno, da posvečamo pozornost pojmom, kot so kolektivna modrost, sinergija in strateško razmišljanje.

Za doseganje splošnega soglasja o domnevah je treba zaradi vpletenosti različnih déležnikov uporabiti različne metode (slika 2). Za zbiranje podatkov o odnosih, potrebah, zahtevah, pričakovanjih in ciljih družbenih skupin v povezavi s pokrajino in njenimi verjetnimi spremembami skozi čas je pomembno, da opravimo polstrukturirane informativne intervjuje z lokalnimi oblastmi, strokovnjaki in vplivnimi osebami ter anketo z vprašalnikom med laiki. Za povečanje veljavnosti ankete, ki temelji na vprašalniku, in zmanjšanje napak v njej je priporočljivo uporabiti pristop verižnega vzorčenja, $s$ katerim konceptualno povežemo strokovnjake, lokalne oblasti in vplivne osebe ter se zlasti izognemo temu, da bi po nepotrebnem izpustili kogar koli med temi skupinami anketirancev. Po dosedanjih izkušnjah (glej Hulse idr., 2004) lokalni prebivalci običajno izberejo tudi predstavnike, ki med izvajanjem projekta redno sodelujejo v razpravah.

Pomen razprave v fokusni skupini je bil potrjen v družboslovnih raziskavah (glej Wilson, 1997). Ta metoda je ključna za povečanje stopnje sodelovanja javnosti, in čeprav je dolgotrajna in včasih zapletena, lahko $\mathrm{z}$ njo učinkovito povežemo laike $s$ strokovnjaki, lokalnimi oblastmi in vplivnimi osebami (slika 3). Poleg tega jo uporabljamo zato, da v nizu srečanj iz poglobljenih intervjujev in skupinskih razprav izluščimo skrite probleme in želje. Rezultat teh srečanj je velik nabor diagramov vzročno-posledičnih zvez in predlogov, ki jih lahko uporabimo za oblikovanje domnev. Z bolj intelektualnega vidika je prirejanje delavnic s strokovnjaki še en način oblikovanja logičnih ciljev in domnev glede alternativnih prihodnosti (glej Nassauer in Corry, 2004). Poleg naštetega je nepogrešljivo tudi navezovanje na uveljavljene vire, še zlasti pri oblikovanju specifičnih domnev. Na področju ekološkega krajinskega načrtovanja so to na primer štirje nepogrešljivi prostorski vzorci, ki jih je vpeljal Richard Forman (1995), ilustrativni vzorci, ki so jih predstavili Wenche Dramstad idr. (1996), smernice za ekološko krajinsko načrtovanje, ki jih je razvila Lauri Karvonen (2000), posebne smernice, ki so jih oblikovali Virginia Dale idr. (2001), in konservatorski pragovi za načrtovalce rabe tal, ki jih je razvil ameriški inštitut za okoljsko pravo (2003), dobri primeri znanstvenih virov, na podlagi katerih lahko oblikujemo domneve za določanje ekoloških alternativ (glej Penteado, 2013).

\subsection{Prikaz}

Nujnost uporabe prostorskega modeliranja pokrajine je že bila natančno opisana in dokazana (Costanza in Voinov, 2004). Prikaz domnev, oblikovanih $\mathrm{v}$ drugem koraku procesa, je močno odvisen od tovrstnih modelov. Pretvorba podatkov iz ustnih virov (vključno z lokalnimi informacijami ter odnosi, potrebami, zahtevami, pričakovanji in cilji ljudi, povezanimi s pokrajino) v prostorsko eksplicitne pokrajinske vzorce ima glavno vlogo pri učinkovitosti in uspehu odločanja, pri katerem je analiza alternativnih prihodnosti in scenarijev glavno orodje. Bistveno je, da pri tem uporabimo ustrezno programsko opremo in izberemo ustrezne modele (glej Cartwright, 2008, ter Pettit in Wyatt, 2009). Ta korak je izjemno pomemben, saj je pretvorba domnev $\mathrm{v}$ obliki besed in besednih zvez $\mathrm{v}$ digitalne zemljevide sestavni del opredelitve različnih smeri in stem prikaza različnih prihodnosti. Raven natančnosti in veljavnosti prostorsko eksplicitnih pokrajinskih vzorcev je močno odvisna 


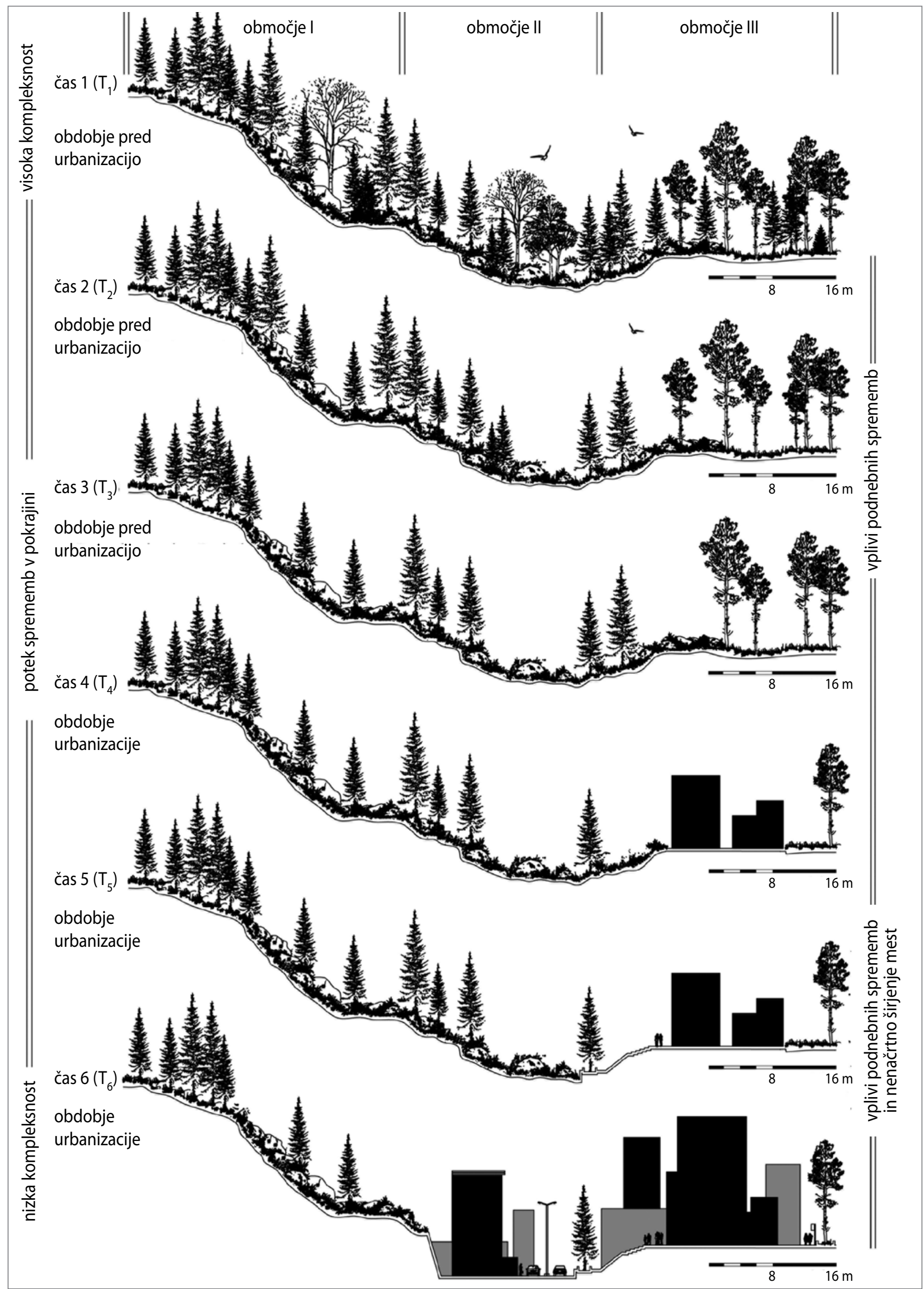

Slika 6: Prikaz poteka sprememb kot posledica vplivov podnebnih sprememb (od $T_{1}$ do $T_{3}$ ) ter vplivov nenačrtnega širjenja mest in podnebnih sprememb (od $\mathrm{T}_{4}$ do $\mathrm{T}_{6}$ ) v prostorski simulaciji pokrajine od visoke do nizke pokrajinske kompleksnosti 
Preglednica 2: Štirje splošni koraki uporabe analize alternativnih prihodnosti in scenarijev v krajinskem načrtovanju v povezavi s podnebnimi spremembami

\begin{tabular}{|c|c|c|}
\hline splošni koraki & podkoraki & preučevane zahteve in vprašanja \\
\hline \multirow{4}{*}{ opredelitev } & & podatki iz ustnih virov: odnosi, potrebe, zahteve, pričakovanja in cilji déležnikov; \\
\hline & zbiranje podatkov & $\begin{array}{l}\text { okoljski podatki: abiotski, biotski in kulturni viri, spremembe v pokrovnosti tal, geohidrološka } \\
\text { gibanja, sestava prsti, razpršitveni vzorci divjih rastlin in živali, človeška gradnja, vzorci rasti } \\
\text { mest in podeželja ter demografska gibanja skozi čas. }\end{array}$ \\
\hline & & $\begin{array}{l}\text { splošne domneve: niz splošnih pravil, ki se določi za vse alternativne prihodnosti pokrajine, } \\
\text { na podlagi katerih se opredeli potek sprememb v pokrajini skozi čas; }\end{array}$ \\
\hline & oblikovanje domnev & $\begin{array}{l}\text { specifične domneve: niz specifičnih pravil, ki se določijo za vsako posamezno alternativno } \\
\text { prihodnost pokrajine posebej, na podlagi česar se opredeli potek sprememb v pokrajini v } \\
\text { določenih okoliščinah skozi čas; }\end{array}$ \\
\hline \multirow{3}{*}{ upodobitev } & & $\begin{array}{l}\text { osnovne opredelitve: obseg, ločljivost in klasifikacija pokrovnosti tal v legendi zemljevida; } \\
\text { programske in strojne zahteve: možnost uporabe programov, kot so Arc GIS, FRAGSTATS, 3-D } \\
\text { Studio Max, Cry Engine in Esri City Engine; }\end{array}$ \\
\hline & & $\begin{array}{l}\text { človeški viri: možnost sodelovanja z visoko usposobljenimi raziskovalci, ki pretvorijo domneve } \\
\text { v prostorsko eksplicitne pokrajinske vzorce; }\end{array}$ \\
\hline & & $\begin{array}{l}\text { mehanizem soglasja: utemeljeni mehanizem, ki omogoča interakcije med raziskovalci, obliko- } \\
\text { valci politike in déležniki v procesu pretvorbe; }\end{array}$ \\
\hline \multirow{3}{*}{ ocenjevanje } & & $\begin{array}{l}\text { opredelitev kazalnikov in meril: niz kvalitativnih in kvantitativnih kazalnikov ter pokrajinskih } \\
\text { meril za sistematično analizo posamezne alternativne prihodnosti pokrajine; }\end{array}$ \\
\hline & & $\begin{array}{l}\text { analitiki: ekipa visoko usposobljenih strokovnjakov, ki opisuje alternativne prihodnosti pokraji- } \\
\text { ne in preučuje njihove prednosti in slabosti; }\end{array}$ \\
\hline & & $\begin{array}{l}\text { večkriterijske odločitvene tehnike: možnost uporabe kvantitativnih metod, kot so SAW, TOPSIS } \\
\text { in ELECTRE, v kombinaciji s kvalitativnimi metodami, kot je metoda Delfi; }\end{array}$ \\
\hline \multirow[t]{2}{*}{ sinteza } & & $\begin{array}{l}\text { kompromisi: razvrščanje alternativnih prihodnosti pokrajine na podlagi družbenoekonomskih, } \\
\text { kulturnih, ekoloških in okoljskih prioritet; }\end{array}$ \\
\hline & & izbor: izbor najbolj utemeljenih alternativnih prihodnosti pokrajine. \\
\hline
\end{tabular}

od natančnosti in kakovosti te pretvorbe. Kot pretvorniki morajo biti raziskovalci visoko usposobljeni, da lahko domneve pravilno pretvorijo. Ta pretvorba sama po sebi izraža odnose in cilje déležnikov, povezane s prihodnostjo pokrajine. Po letu 2000 so tridimenzionalni prikazi alternativnih prihodnosti postali razširjena metoda izboljšanja ravni percepcije prostorskih in časovnih konceptov med laiki (na primer Hulse idr., 2004; Nassauer in Corry, 2004; Berger in Brown, 2008, ter Mansergh idr., 2008). Poleg tega je pri oblikovanju scenarijev ključna tudi uporaba novih tehnik, kot so celični avtomati (glej Maxwell idr., 2004; Clarke, 2008, in Liu, 2009). V anketi se je večina anketirancev strinjala, da je pretvorba podatkov v prostorsko eksplicitne pokrajinske vzorce še vedno velik izziv pri projektih krajinskega načrtovanja, ki temeljijo na alternativnih prihodnostih. Anketa je pokazala, da se s tem stališčem »močno strinja « ali »strinja « okrog $90 \%$ anketirancev. Na podlagi pregleda velikega števila študij primerov z vsega sveta lahko za pretvorbo neprostorskih podatkov v prostorsko eksplicitne pokrajinske vzorce predlagamo preprost, toda pomemben model (slika 4). Model ponazarja, kako lahko različne vrste podatkov pretvorimo v uporabne prostorsko eksplicitne pokrajinske vzorce. Nazadnje morajo biti končni rezultati ponazoritve, ki jih lahko zlahka razumemo (sliki 5 in 6).

\subsection{Ocenjevanje in sinteza}

Kljub vsem napredkom, doseženim na tem področju, pri ocenjevanju alternativnih prihodnosti še vedno lahko naletimo na najrazličnejše omejitve (Corry in Nassauer, 2005). V splošnem bi morali v ocenjevalni proces vključiti skupino izkušenih strokovnjakov, ki bi alternativne prihodnosti analizirala na podlagi izbranih meril. $\mathrm{V}$ ta namen bi bilo dobro in ustrezno uporabiti večkriterijske kvantitativne odločitvene metode, kot so SAW (ang. simple additive weighting), TOPSIS (ang. technique for order preference by similarity to ideal solution) in ELECTRE (ang. elimination and choice expressing reality), ter kvalitativne metode, kot je metoda Delfi (glej Hwang in Yoon, 1981; Pimerol in Romero, 2000, ter Linstone in Turoff, 2002). V tem koraku je najtežja naloga najti skupni jezik med strokovnjaki z različnih področij, ki naj bi ocenili alternativne prihodnosti in scenarije. Ustrezno orodje za lajšanje te komunikacije je lahko Arc GIS. 


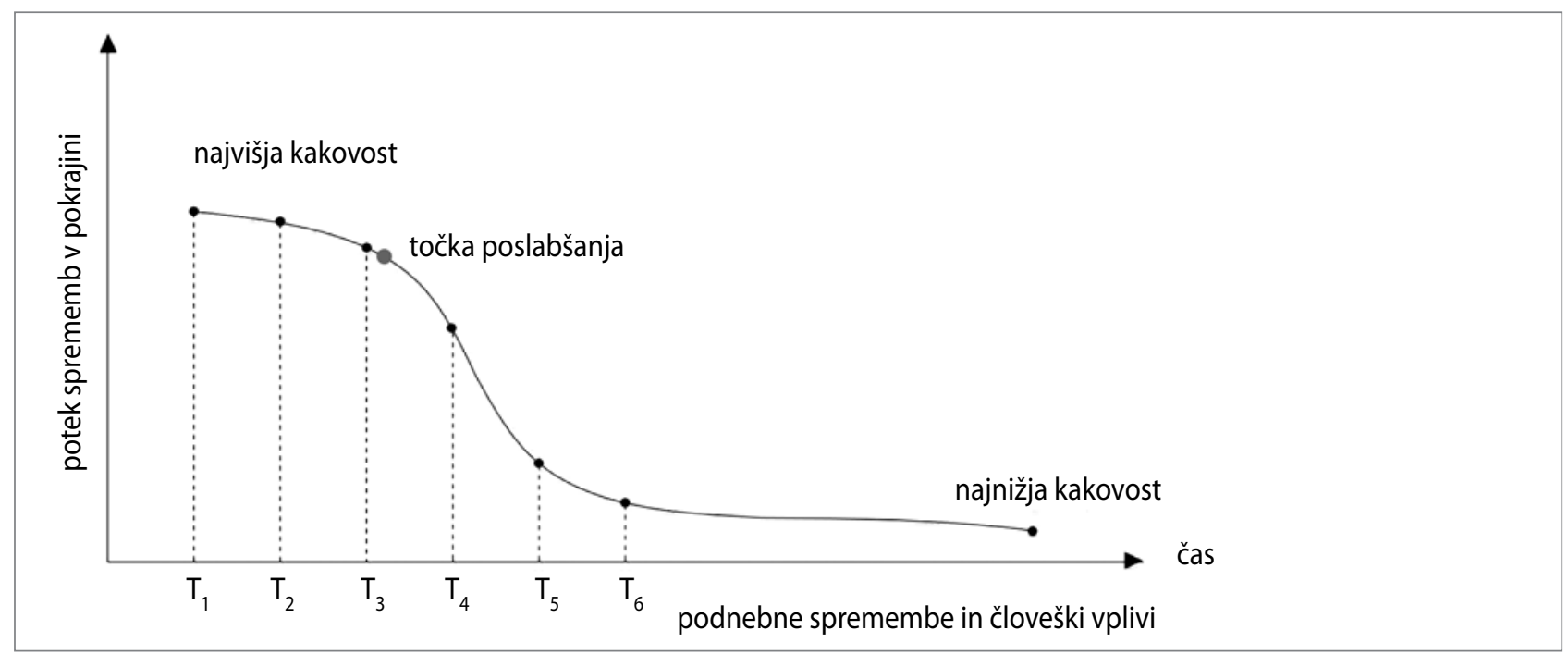

Slika 7: Potek sprememb v biološki zgradbi pokrajine v povezavi s spremembami kakovosti življenja od obdobja pred urbanizacijo (od $\mathrm{T}_{1}$ do $\mathrm{T}_{3}$ ) do obdobja urbanizacije (od točke poslabšanja naprej)

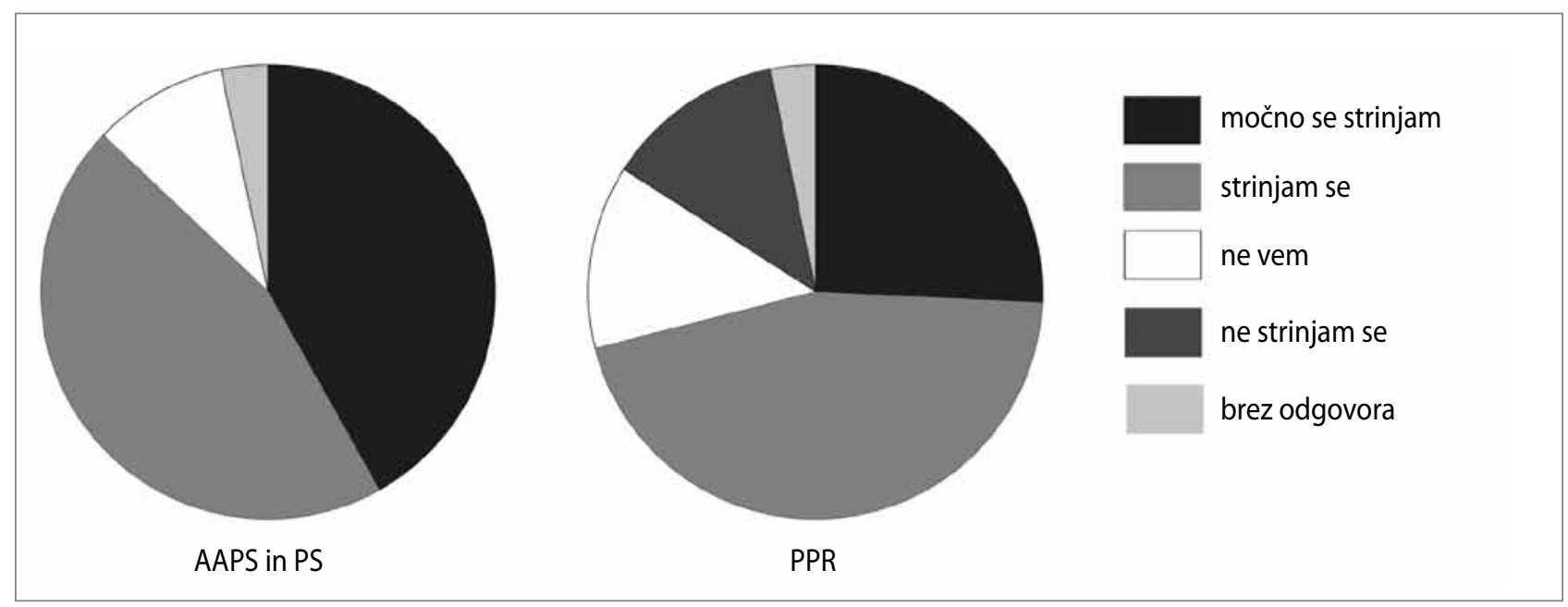

Slika 8: (a) Vloga analize alternativnih prihodnosti in scenarijev (AAPS) pri blaženju podnebnih sprememb (PS) in prilagajanju nanje; (b) potreba po razvijanju pristopa (PPR) v naslednjih desetletjih

Opomba: (a) AAPS in PS: »močno se strinjam $=42 \%$, »strinjam se $=45 \%$, »ne vem« $=10 \%$, »brez odgovora« $=3 \%$; (b) PPR: »močno se strinjam $=26 \%$, »strinjam se $=45 \%$, »ne vem $«=13 \%$, »ne strinjam se $=13 \%$, »brez odgovora $=3 \%$

Pri ocenjevanju je treba opredeliti pokrajinska merila, povezana s podnebnimi spremembami. Tako podnebne spremembe kot človeške vplive lahko merimo $s$ kvantitativnimi metodami. Lahko pa iz navadnih meril sestavimo nova. Kompleksnost biološke zgradbe pokrajine je na primer merilo, na podlagi katerega lahko primerjamo spremembe $\mathrm{v}$ pokrajini v daljšem časovnem obdobju v fazi ocenjevanja in sinteze (slika 7). V tem primeru lahko združimo niz meril, povezanih z zgradbo in konfiguracijo pokrajine, in določimo učinkovitejše merilo za ocenjevanje.

\subsection{Pogledi, težave in vrzeli}

V splošnem med strokovnjaki vlada močno soglasje glede učinkovitosti analize alternativnih prihodnosti in scenarijev kot odločitvenega pristopa na področju krajinskega načrtovanja. Rezultati ankete kažejo, da se s tem stališčem močno strinja približno $74 \%$ vprašanih, $23 \%$ pa se z njim strinja. Med anketiranci ni bilo nikogar, ki se $s$ tem ne bi strinjal. Rezultat kaže, da je uporaba alternativnih prihodnosti po svetu veljavno orodje za zamišljanje prihodnosti pokrajine. Številke kažejo, da se anketiranci strinjajo, da ima ta pristop nepogrešljivo vlogo pri reševanju vprašanj krajinskega načrtovanja. Rezultati ankete poleg tega potrjujejo, da se uporaba tega pristopa pri sprejemanju odločitev glede pokrajin v različnih državah povečuje. Rezultati nakazujejo, da lahko ta pristop uporabimo tudi za razvijanje znanja o krajinski ekologiji pri praktičnih projektih s področja krajinskega načrtovanja. Okrog $90 \%$ anketirancev se močno strinja ali strinja, da lahko uporaba analize alternativnih prihodnosti in scenarijev $\mathrm{v}$ krajinskem načrtovanju prispeva $\mathrm{k}$ 
boljši ozaveščenosti o krajinski ekologiji in obratno. Presenetljivo je, da pri tem vprašanju ni bilo zabeleženega nobenega nestrinjanja med anketiranci.

Odgovori, pridobljeni v anketi, dalje kažejo, da bi lahko ta pristop v 21. stoletju pogosteje in širše uporabljali, saj gre za horizontalno krajinsko načrtovalsko orodje, ki se lahko uporablja v različne namene. Večina vprašanih (približno 87 \%) se strinja, da je lahko analiza alternativnih prihodnosti in scenarijev učinkovit pristop $\mathrm{k}$ reševanju problematike podnebnih sprememb, saj omogoča prikaz prostorsko eksplicitnih pokrajinskih vzorcev in prostorskih sprememb, ki so posledica podnebnih sprememb, skozi določeno časovno obdobje. Približno $71 \%$ anketirancev meni, da je ta pristop še v začetni fazi in da bi ga bilo treba v prihodnjih desetletjih še bolj razviti (slika 8). Ta ugotovitev kaže, da zlasti raziskovalci, ki se ukvarjajo z alternativnimi prihodnostmi pokrajine, posvečajo veliko pozornosti podnebnim spremembam. Kljub temu pa nekateri odgovori izražajo določeno mero skepticizma glede vloge tega pristopa kot orodja za odločanje o pokrajinah na podlagi prikaza strategij za blaženje podnebnih sprememb. Eden od anketirancev je na primer izjavil:

Trenutno močno dvomim, da so lahko alternativne prihodnosti uporabno orodje za blaženje podnebnih sprememb. Negotovost glede tega, kako se bo podnebje spreminjalo in še zlasti kako se bodo ekosistemi odzvali na podnebne spremembe, je prevelika. Če pa bi se modeli podnebnih sprememb in ekosistemov pomembno izboljšali, tako da bi se ta negotovost močno zmanjšala, bi jih bilo mogoče vendarle smiselno vključiti v proces alternativnih prihodnosti.

Kljub temu še vedno obstajajo deljena mnenja glede določenih vprašanj. S praktičnega vidika na primer ni enotnega mnenja o natančnem številu alternativnih prihodnosti, ki bi jih bilo treba določiti v posameznem projektu krajinskega načrtovanja. $16,13,10$ in $19 \%$ anketirancev je izjavilo, da bi moralo biti število teh alternativnih prihodnosti tri, štiri, pet in več kot pet, medtem ko jih približno 29 \% meni, da natančnega števila ni mogoče določiti. Poleg tega so trije anketiranci prepričani, da bi moralo biti to število med tri in pet, eden anketiranec pa na to vprašanje ni odgovoril.

Kljub vsemu napredku in dosežkom pri uporabi tega pristopa za odločanje in krajinsko načrtovanje je treba $\mathrm{v}$ praksi rešiti še veliko problemov. Da bi določili najtežavnejše korake tega pristopa v praksi, smo preučili številne projekte (na primer Theobold in Hobbs, 2002; Hunter idr., 2003; Steinitz idr., 2003; Aycrigg idr., 2004; Berger in Bolte, 2004; Hulse idr., 2004; Nassauer in Corry, 2004; Schumaker idr., 2004; Sharma idr., 2005; Bryan idr., 2008; Patel idr., 2007; Kepner idr., 2008; Soliva idr., 2008; Hulse idr., 2009; Verburg idr., 2010; Oana idr., 2011, ter Morley idr., 2012). Anketiranci so morali

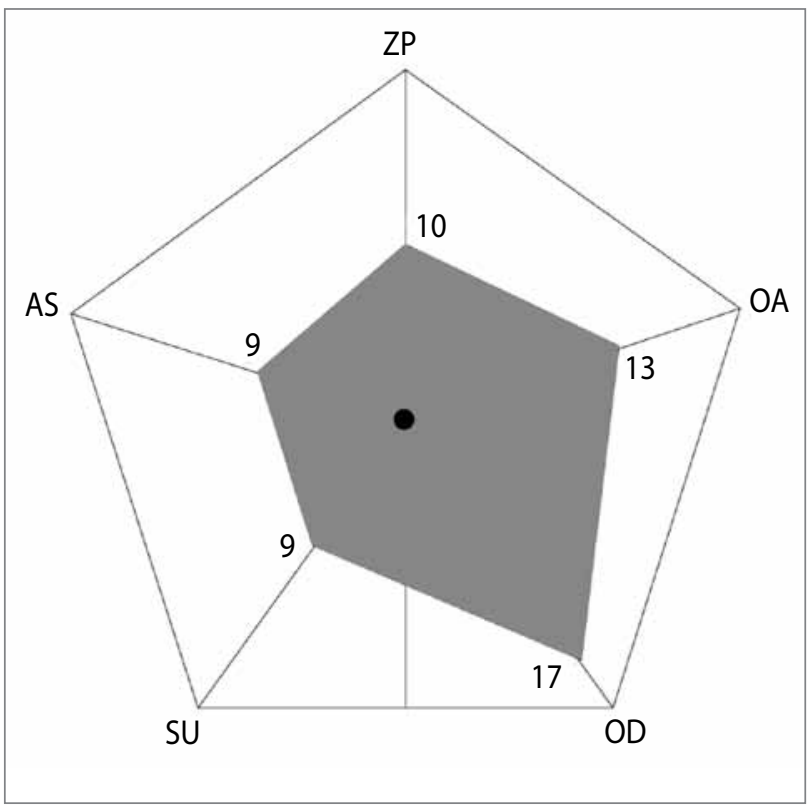

Slika 9: Pet glavnih korakov uporabe analize alternativnih prihodnosti in scenarijev $v$ krajinskem načrtovanju: zbiranje podatkov (ZP), opredelitev alternativnih prihodnosti (OA), oblikovanje domnev (OD), simulacija in upodobitev scenarijev (SU) ter analiza scenarijev (AS). Stopnja težavnosti posameznega koraka v praksi je bila določena na podlagi tega, kolikokrat so ga kot takega izbrali anketiranci.

navesti, s katerimi izzivi in težavami se srečujejo pri svojem delu. Rezultati so pokazali, da je 17 anketirancev kot najtežavnejši korak tega pristopa izbralo dejavnik »oblikovanje domnev« (OD). Kot drugi najtežavnejši korak je bila izbrana $\gg$ opredelitev alternativnih prihodnosti $(\mathrm{OA})$ na podlagi projektnih zahtev, ciljev in raziskovalnih vprašanj. »Zbiranje podatkov « (ZP) pa je izbralo deset anketirancev. Ti trije koraki so opisani v »opredelitvi«, prvem koraku mehanizma, kar potrjuje, da je prvi korak pri tovrstnih projektih izjemno pomemben. Rezultati kažejo, da sta fazi »simulacija in upodobitev scenarijev « (SU) ter »analiza scenarijev « (AS) za anketirance manj težavni (slika 9). V nekaterih primerih so anketiranci pri odgovorih dodali podrobnejšo razlago. Eden od strokovnjakov je na primer navedel, da so vsi koraki pomembni, da pa je zbiranje podatkov in zgodovinskega gradiva o pokrajini predpogoj za naslednje korake:

Prvo možnost [zbiranje podatkov in zgodovinskega gradiva o pokrajini] sem izbral zato, ker če ti tu spodleti, ti bo spodletelo tudi v naslednjih fazah. Če zbiraš zgodovinske podatke na podlagi neprostorskih podatkov, na primer z intervjuvanjem ljudi, so lahko rezultati dobri, vendar se ljudje pogosto ne spomnijo pravilnega časa in kraja, poleg tega pa se lahko zgodbe med ljudmi razlikujejo. Pri zbiranju prostorskih podatkov, na primer zgodovinskih kart, je treba poznati postopek in namen kartiranja, saj se te karte od sedanjih močno razlikujejo. V svojem projektu smo na primer uporabili zgodovinske karte parcelacije, katerih namen je bil razdeliti rodovitna in nerodovitna kmetijska zemljišča enakomerno med različna gospodinjstva. 
Preglednica 3: Najpomembnejše izjave, povzete iz odgovorov na vprašanja odprtega tipa, glede ustreznega obsega analize alternativnih prihodnosti in scenarijev

\begin{tabular}{|c|c|c|}
\hline odnosi & omenjene spremenljivke & primeri najpomembnejših izjav \\
\hline \multirow{14}{*}{ obseg ni določen } & \multirow[t]{2}{*}{$\begin{array}{l}\text { narava problema, narava } \\
\text { udeležencev }\end{array}$} & $\begin{array}{l}\text { To je močno odvisno od narave problema in udeležencev, vendar obseg ne bi smel } \\
\text { biti premajhen (to je manjši od približno } 10 \times 10 \mathrm{~km}^{2} \text { ) niti prevelik (to je večji od } \\
100 \times 100 \mathrm{~km}^{2} \text { ). Vedeti je treba, da lahko scenarije razvijemo za veliko večja obmo- } \\
\text { čja (celo za ves svet), vendar se mora načrtovanje osredotočiti na manjša območja. }\end{array}$ \\
\hline & & $\begin{array}{l}\text { To je odvisno od tega, kdo potrebuje te podatke. Glede na trenutno stopnjo razu- } \\
\text { mevanja in negotovosti, povezane } z \text { napovedmi podnebnih sprememb, se ne zdi } \\
\text { smiselno upoštevati območja, manjša od } 10^{5} \text { ha. }\end{array}$ \\
\hline & \multirow{4}{*}{$\begin{array}{l}\text { raziskovalno vprašanje, } \\
\text { vrsta pokrajine }\end{array}$} & Odvisno od raziskovalnega vprašanja in vrste pokrajine. \\
\hline & & Velikost območja je odvisna od zastavljenih vprašanj glede sprememb pokrajine. \\
\hline & & Odvisno od raziskovalnega vprašanja in vrste pokrajine. \\
\hline & & $\begin{array}{l}\text { Alternativne prihodnosti se lahko nanašajo na celotno preučevano območje ali } \\
\text { samo na njegov del, odvisno od spremenljivke. }\end{array}$ \\
\hline & \multirow{5}{*}{$\begin{array}{l}\text { cilj projekta, značilnosti } \\
\text { pokrajine }\end{array}$} & Odvisno od ciljev projekta, značilnosti pokrajine in obsega. \\
\hline & & $\begin{array}{l}\text { Odvisno od obsega projekta (regionalni, podregionalni, zajeti podatki, matrica po- } \\
\text { krajine) in njegovega konteksta. }\end{array}$ \\
\hline & & Odvisno od preučevanega območja. \\
\hline & & Lahko se razlikuje glede na razdrobljenost območja. \\
\hline & & Odvisno od mesta: treba je vključiti celotno mestno območje. \\
\hline & razpoložljivost podatkov & $\begin{array}{l}\text { Ko postane prostorski obseg analize manjši, mora prostorska zgradba podatkov } \\
\text { postati podrobnejša, tudi podatki in modeli morajo biti natančnejši. }\end{array}$ \\
\hline & \multirow{2}{*}{ ločljivost } & Raje imam čim večjo. Ločljivost je pomembna. \\
\hline & & Odvisno od podatkov o pokrovnosti tal do ločljivosti $30 \times 30 \mathrm{~m}^{2}$. \\
\hline \multirow{2}{*}{\multicolumn{2}{|c|}{ določen je natančen obseg }} & $\mathrm{P}>100 \mathrm{~km}^{2} ; \mathrm{P}>1.000 \mathrm{~km}^{2} ; 1 \leq \mathrm{P} \leq 100 \mathrm{~km}^{2} ; 10 \leq \mathrm{P} \leq 100 \mathrm{~km}^{2}$. \\
\hline & & $100 \leq P \leq 10.000 \mathrm{~km}^{2} ; 5.000 \leq \mathrm{P} \leq 50.000 \mathrm{~km}^{2}$. \\
\hline \multirow{3}{*}{ drugi odgovori } & & Potrebujemo najmanj tri različne obsege. \\
\hline & & Lahko gre za kateri koli obseg: od posamezne lokacije do celega sveta. \\
\hline & & Pomembneje je, da upoštevamo območje in problematiko v celoti. \\
\hline
\end{tabular}

Preglednica 4: Odvisnost pristopa od osmih kvalitativnih dejavnikov, ki vplivajo na izvedbo pristopa v projektih krajinskega načrtovanja

\begin{tabular}{|c|c|c|c|c|c|c|c|}
\hline Dejavniki & Likertova les & $a(\%)$, ponderiran & (w) od 5 do 1 & & & & \\
\hline & $\begin{array}{l}\text { močno se } \\
\text { strinjam (\%) } \\
w=5\end{array}$ & $\begin{array}{l}\text { strinjam se (\%) } \\
\text { w }=4\end{array}$ & $\begin{array}{l}\text { ne vem }(\%) \\
w=3\end{array}$ & $\begin{array}{l}\text { ne strinjam se } \\
(\%) \\
w=2\end{array}$ & $\begin{array}{l}\text { močno se ne } \\
\text { strinjam (\%) } \\
w=1\end{array}$ & $\begin{array}{l}\text { brez odgovora (\%) } \\
\mathrm{w}=0\end{array}$ & $\begin{array}{l}\text { skupno število } \\
\text { točk }\left(\Sigma S_{i} \times W_{j}\right)\end{array}$ \\
\hline SLP & 36 & 45 & 19 & 0 & 0 & 0 & 417 \\
\hline LEZ & 32 & 42 & 16 & 10 & 0 & 0 & 396 \\
\hline PRO & 26 & 42 & 19 & 10 & 0 & 3 & 375 \\
\hline SPM & 6 & 52 & 26 & 13 & 3 & 0 & 345 \\
\hline OD & 61 & 26 & 10 & 3 & 0 & 0 & 445 \\
\hline VPT & 7 & 23 & 45 & 16 & 3 & 6 & 297 \\
\hline UČV & 36 & 61 & 3 & 0 & 0 & 0 & 433 \\
\hline MOM & 26 & 29 & 19 & 23 & 0 & 3 & 349 \\
\hline povprečje ( ) & 28,6 & 40 & 19,5 & 9,2 & 0,6 & 2,1 & 389 \\
\hline
\end{tabular}




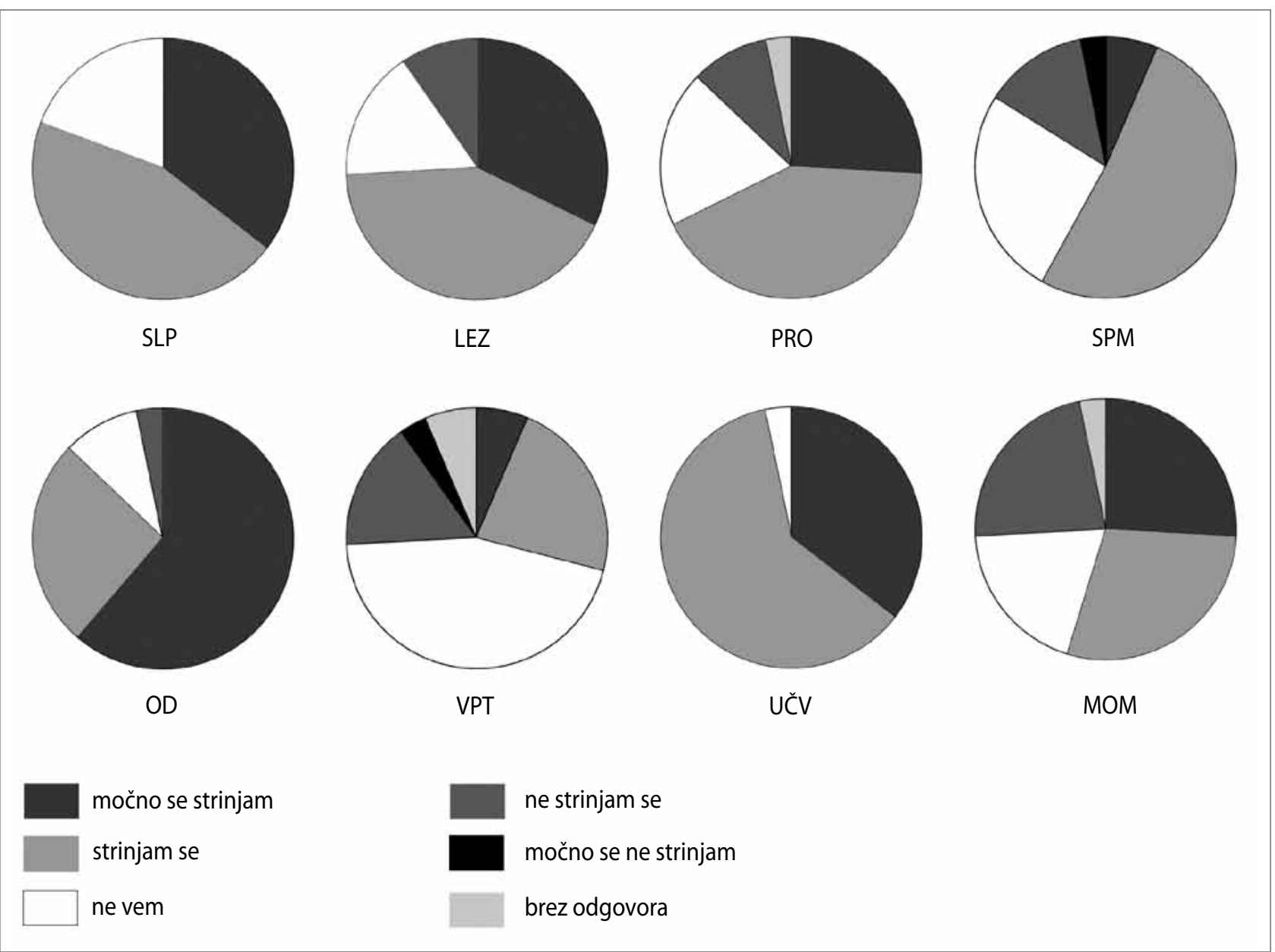

Slika 10: Odvisnost pristopa od osmih kvalitativnih dejavnikov, ki vplivajo na izvedbo pristopa v projektih krajinskega načrtovanja

Opomba: SLP = sodelovanje lokalnega prebivalstva, LEZ = lokalno ekološko znanje, PRO = programska oprema, SPM = statistični pojmi in metode, OD = oblikovanje domnev, VPT = vrste pokrovnosti tal, UČV = usposobljeni človeški viri, MOM= metode in orodja modeliranja

Za interpretacijo teh kart moraš najprej razumeti, da vse kategorije na karti temeljijo na rodovitnosti zemljišč in da so bile natančno kartirane samo najrodovitnejše parcele.

Naslednja težava, ugotovljena $\mathrm{v}$ anketi, je povezana z izbiro ustreznega obsega in ločljivosti. Veliko anketirancev meni, da bi moral biti obseg raziskave prostorsko velik, vendar glede natančnega obsega uporabe analize alternativnih prihodnosti in scenarijev v krajinskem načrtovanju ni enotnega mnenja. Analiza študij primerov kaže, da lahko raziskava zajema tako posamezno lokacijo kot cel svet. To so potrdili tudi rezultati ankete (preglednica 3). Čeprav se zdi, da gre pri uporabi logičnih meril za izbiro ustreznega obsega in ločljivosti za določene podobnosti, nekateri raziskovalci raje izbirajo različne obsege za različne okoliščine. Eden glavnih razlogov za to je slaba dostopnost natančnih prostorskih podatkov, vključno s posodobljenimi satelitskimi in zračnimi posnetki. Čeprav so nekateri anketiranci navedli natančno določen obseg in ločljivost, jih večina ni navedla natančno določenega standarda, ki bi ga uporabili pri izbiri obsega in ločljivosti. Ta skupina anketiran- cev je omenila različne spremenljivke, ki so vplivale na njihove odgovore. Odgovori v anketi kažejo, da je treba obseg izbrati za vsak primer posebej, in sicer na podlagi raziskovalnih ciljev.

Poleg teh spornih vprašanj obstajajo še večje težave in vrzeli, ki bi jih bilo treba preučiti za prihodnji razvoj tega pristopa. Odgovori kažejo, da nekatere praktične težave zahtevajo večjo pozornost. Eden od anketirancev je izjavil:

\section{/.../ [N]ajvečja težava je pravzaprav to, kako načrtovalce in odlo- čevalce pripraviti do tega, da uporabljajo informacije in rezultate analize scenarijev /.../}

Uporaba analize alternativnih prihodnosti in scenarijev je odvisna od širokega spektra zahtev in pogojev, od človeških virov do tehnoloških orodij. $\mathrm{V}$ veliko primerih je bil ta pristop neuspešen zaradi pomanjkljivosti in slabosti teh zahtev in pogojev. $\mathrm{Z}$ uporabo vprašanj z izbiro, oblikovanih na podlagi Likertove lestvice, smo določili osem dejavnikov, od katerih je odvisen preučevani pristop: sodelovanje lokalnega prebivalstva (SLP), 
Preglednica 5: Podatki o trenutnih skrbeh in težavah, povezanih z uporabo analize alternativnih prihodnosti in scenarijev pri krajinskem načrtovanju

\begin{tabular}{ll}
\hline kategorija & trenutne skrbi in težave \\
\hline \multirow{2}{*}{ obseg in velikost } & Pomanjkanje ustreznega obsega in ločljivosti zaradi nerazpoložljivosti učinkovite tehnolo- \\
& ške infrastrukture in orodij. \\
& Pomanjkanje natančnih kopenskih podatkov. \\
\hline
\end{tabular}

oblikovanje soglasja glede opredelitve alternativnih prihodnosti
Težave pri ugotavljanju vertikalnih in horizontalnih odnosov med ljudmi, lokalnimi oblast$\mathrm{mi}$, strokovnjaki in raziskovalci.

Razhajanja pri določanju ciljev, povezanih s pokrajino, zaradi velikih razlik v kulturnem, gospodarskem in družbenem ozadju déležnikov.

Težave pri zagotavljanju dolgoročne platforme za ljudi in njihove predstavnike, ki naj bi pomagali oblikovati soglasje glede opredelitve alternativnih prihodnosti.

Pomanjkanje zgodovinskih podatkov o preučevani pokrajini.

Dolgotrajnost procesa, zlasti pri oblikovanju specifičnih domnev za vsako posamezno alternativno prihodnost.

oblikovanje domnev

Vidne razlike med vizijami ljudmi o prihodnosti pokrajine.

Negotovosti glede prihodnosti.

Pomanjkanje zadostnega zaupanja v prihodnost.

Kompleksno pretvarjanje besed, besednih zvez, besedil, skic, diagramov in grafikonov v prostorsko eksplicitne pokrajinske vzorce.

Nezadostne spretnosti pri simulaciji in prostorskem modeliranju.

Zapleten izbor ustreznih kvalitativnih in kvantitativnih kazalnikov za primerjavo alternativnih prihodnosti.

Težave pri prekrivanju ocen, ki jih pripravijo posamezne skupine strokovnjakov. lokalno ekološko znanje (LEZ), programska oprema (PRO), statistični pojmi in metode (SPM), oblikovanje domnev (OD), vrste pokrovnosti tal (VPT), usposobljeni človeški viri (UČV) ter metode in orodja modeliranja (MOM). Rezultati kažejo, da sta oblikovanje domnev (OD) in usposobljeni človeški viri (UČV) najpomembnejša dejavnika uporabe analize alternativnih prihodnosti in scenarijev $\mathrm{v}$ krajinskem načrtovanju, ki vplivata na kakovost in natančnost projekta. Sledijo sodelovanje lokalnega prebivalstva (SLP), lokalno ekološko znanje (LEZ), programska oprema (PRO), metode in orodja modeliranja (MOM), statistični pojmi in metode (SPM) in število vrst pokrovnosti tal (VPT). Da bi dobili smiselno statistično podobo vrednosti in pomena vsakega dejavnika, smo ponderirali posamezna števila in rezultate (preglednica 4 in slika 10).

Jasno je, da je uporaba analize alternativnih prihodnosti in scenarijev splošno sprejet pristop pri sprejemanju odločitev o pokrajinah. Poleg tega je bil dosežen določen napredek pri razvoju tega pristopa, ki omogoča njegovo uporabo pri odločanju o vprašanjih, povezanih s podnebnimi spremembami. Kljub temu na tem področju še vedno obstajajo določene skrbi in težave, ki jih je treba rešiti. $\mathrm{V}$ raziskavi smo jih razvrstili glede na ugotovitve pregleda literature in rezultate ankete (pregle- dnica 5). Anketiranci so navedli več razlogov za obstoj teh težav. Zgoraj omenjena analiza praktičnih projektov je razkrila potrebo po izboljšanju, razvoju in posodobitvi tega pristopa, ki bi $s$ tem postal uporabnejši v obdobju podnebnih sprememb. Ti ukrepi bi morali vključevati vsa vprašanja, povezana z uporabo alternativnih prihodnosti.

\section{Sklep}

Raziskava je pokazala, da lahko uporaba analize alternativnih prihodnosti in scenarijev pri krajinskem načrtovanju zagotavlja odlično podlago za preučevanje verjetnih vplivov prilagoditvenih in blažilnih strategij na prihodnost pokrajine z vidika podnebnih sprememb. Pristop ponuja odločevalcem odlično priložnost za to, da razširijo svoj pogled in sprejmejo ustrezno krajinsko politiko, še preden z vidika trajnostnega razvoja dosežejo točko, $s$ katere ni več vrnitve. Nepravilna uporaba te metode je lahko zavajajoča in lahko negativno vpliva na proces odločanja ter $s$ tem na sprejeto krajinsko politiko. Ta pristop je lahko ključni politični inštrument za vključevanje vplivov podnebnih sprememb, družbenih vrednot in ekoloških razmer $\mathrm{v}$ proces odločanja pri načrtovanju pokrajin. Uporaba tega pristopa labko zmanjša splošna nasprotja med déležniki, ki imajo 
popolnoma različne vrednote in odnose. Analiza alternativnih prihodnosti in scenarijev je večdimenzionalni mehanizem, $s$ katerim lahko sprejemamo informirane odločitve na podlagi kolektivnega vedenja.

Zaradi najnovejših tehnoloških napredkov lahko postane ta pristop učinkovitejši kot kadar koli prej. V prihodnosti bi lahko satelitski posnetki olajšali zbiranje zgodovinskih pokrajinskih podatkov. Ker se programska oprema naglo razvija, postaja tudi simulacija pokrajin vse bolj realna in logična možnost. Obenem je uporaba tovrstnih tehnoloških orodij vse naprednejša in zahteva bolje usposobljene človeške vire. Medtem ko tehnologija napreduje, bi bilo treba posodobiti in obogatiti tudi pokrajinske podatkovne zbirke. Priprava biološko-geološko-podnebnih kart pokrajine v vsaki regiji zagotavlja odlično podlago za določanje obnovitvenih alternativnih prihodnosti in alternativnih prihodnosti, odpornih proti podnebnim spremembam. Ko je tovrstna karta na voljo, lahko z opredelitvijo specifičnih alternativnih prihodnosti oblikujemo načrt pretvorbe trenutnih pokrajinskih vzorcev v ekološko obnovljive. Poznavanje naravne zgodovine pokrajine je še eden od pomembnih dejavnikov, ki zagotavljajo, da so obnovitvene alternativne prihodnosti in alternativne prihodnosti, odporne proti podnebnim spremembam, pravilno opredeljene.

Raziskava je pokazala, da je še vedno prisotna velika potreba po razvoju metod in tehnologij, s katerimi bi lahko utemeljene in zanesljive domneve pretvorili $\mathrm{v}$ realistične prostorsko eksplicitne pokrajinske vzorce. $\mathrm{V}$ tem primeru lahko $\mathrm{z}$ uporabo slikovnih vprašalnikov in ponazoritvenih skic zlasti med laiki razvijemo razumevanje vplivov podnebnih sprememb na prihodnost pokrajine. Sodelovanje ljudi ima pomembno vlogo pri zbiranju podatkov in oblikovanju domnev, zaradi česar je pomembno, da na različne načine spodbujamo njihovo sodelovanje pri teh dejavnostih. Nekatere spletne rešitve (na primer spletna družbena omrežja) lahko uporabimo za odpravljanje geografske oddaljenosti, raziskovalci pa lahko z njihovo pomočjo rešijo določene težave, povezane s sodelovanjem javnosti. Ljudje, ki živijo v določeni pokrajini, lahko izboljšajo možnosti doseganja uspeha, če svojo vlogo igrajo pravilno. Vsi upravičenci bi morali imeti besedo $\mathrm{v}$ celotnem procesu odločanja in sprejemanja krajinske politike. Pravičnost je v tem primeru izjemno pomembna. Družba ima pravico izbrati svojo usodo na podlagi aktivnega sodelovanja in informiranih odločitev. Če se ljudje čutijo povezani s projektom, želijo aktivno sodelovati v vseh njegovih fazah. Lokalni lastniki zemljišč imajo lahko kot potencialne gonilne sile načrtov obnove pokrajine na podlagi splošnega soglasja prav tako odločilno vlogo pri zagotavljanju uspešnosti sprejetih odločitev.

Za sprejemanje krajinske politike $\mathrm{v}$ povezavi z vplivi podnebnih sprememb bi bilo treba zbrati nove vrste podatkov, obli- kovati bi bilo treba nove domneve, uporabiti nove simulacijske tehnike in opredeliti nova merila ocenjevanja alternativnih prihodnosti. Poleg tega bi bilo treba pri reševanju vprašanj, povezanih s podnebnimi spremembami, upoštevati tudi krajinsko ekologijo kot transdisciplinarno vedo, saj je to odločilno za določanje novih alternativnih prihodnosti na začetku projekta in za opredelitev meril njihovega ocenjevanja na koncu projekta. Raziskava utira pot preučevanju morebitnih prednosti tega pristopa pri odločanju in sprejemanju politik glede prihodnosti pokrajine, pri čemer so urbanizacija in podnebne spremembe glavna gonila neizbežnih sprememb. Poleg tega spodbuja druge raziskovalce, naj preučijo trenutne vrzeli, težave in poglede, povezane s tem pristopom, ter tako omogočijo njegovo boljšo in učinkovitejšo uporabo v prihodnosti.

\section{Amin Rastandeh}

Tarbiat Modares University, Teheran, Iran

E-pošta: amin.rastandeh@yahoo.com

\section{Viri in literatura}

Acharya, A. K., in Barragán Codina, M. R. (2012): Social segregation of indigenous migrants in Mexico: An overview from Monterrey. Urbani izziv, 23(1), str. 140-149. DOI: 10.5379/urbani-izziv-en-2012-23-01-006

Ahern, J. (1997): At the crossroads: Sustainable future or urban sprawl? Spatial concepts and scenarios for the Lisbon metropolitan area. V: Reis Machado, in J., Ahern, J. (ur.): Environmental challenges in an expanding urban world and the role of emerging information technologies, str. 1326. Lizbona, CNIG.

Ahern, J. (1999): Spatial concepts, planning strategies and future scenarios: A framework method for integrating landscape ecology and landscape planning. V: Klopatek, J., in Gardner, R. (ur.): Landscape ecological analysis: Issues and applications, str. 175-201. New York, Springer. DOI: 10.1007/978-1-4612-0529-6_10

Ahern, J. (2007): Green infrastructure for cities: The spatial dimension. V: Novotny, V., Breckenridge, L., in Brown, P. (ur.): Cities of the future: Towards integrated sustainable water and landscape management, str. 267-283. London, IWA Publishing.

Alberti, M., in Marzluff, J. M. (2004): Ecological resilience in urban ecosystems: linking urban patterns to human and ecological functions. Urban Ecosystems, 7(3), str. 241-265.

DOI: 10.1023/B:UECO.0000044038.90173.c6

Aycrigg, J. L., Harper, S. J., in Westervelt, J. D. (2004): Simulating land use alternatives and their impacts on a desert tortoise population in the Mojave Desert, California. V: Costanza, R., in Voinov, A. (ur.): Landscape simulation modeling: A spatially-explicit, dynamic approach, str. 249-273. New York, Springer. DOI: 10.1007/0-387-21555-7_10

Baker, J. P., Hulse, D. W., Gregory, S. V., White, D., Van Sickle, J., Berger, P. A., idr. (2004): Alternative futures for the Willamette River Basin, Oregon. Ecological Applications, 14(2), str. 313-324. DOI: 10.1890/02-5011

Bao, L. Q., Park, S. J., in Vlec, P. L. G. (2010): Land Use Dynamic Simulator (LUDAS): A multi-agent system model for simulating spatio-temporal dynamics of coupled human-landscape system 2.Scenario-based application for impact assessment of land-use policies. Ecological Informatics, 5(3), str. 203-221. DOI: 10.1016/j.ecoinf.2010.02.001

Barre, R. (2004): Participative and coherent scenario building: An input/ output balance model: The case of the French national futuris operation. 
Prispevek je bil predstavljen na konferenci z naslovom New Technology Foresight, Forecasting and Assessment Methods, ki je potekala od 3. do 14. maja v Sevilli v Španiji. Tipkopis.

Bell, S. (1999): Landscape: Pattern, perception, and process. London, F \& FN SPON.

Bender, O., Boehmer, H. J., Jens, D., in Schumacher, K. P. (2005): Using GIS to analyse long-term cultural landscape change in southern Germany. Landscape and Urban Planning, 70(1-2), str. 111-125. DOI: 10.1016/j.landurbplan.2003.10.008

Berger, P., in Bolte, J. (2004): Evaluating the impact of policy options on agricultural landscapes: An alternative futures approach. Ecological Applications, 14(2), str. 342-354. DOI: 10.1890/02-5069

Berger, A., in Brown, C. (2008): Digital simulation and reclamation: Strategies for altered landscapes. V: Berger, A. (ur.): Designing the reclaimed landscape, str. 115-124. New York, Taylor \& Francis.

Botequilha Leitão, A., in Ahern, J. (2002): Applying landscape ecological concepts and metrics in sustainable landscape planning. Landscape and Urban Planning, 59(2), str. 65-93. DOI: 10.1016/50169-2046(02)00005-1

Botequilha Leitão, A., Miller, J., Ahern, J., in McGarigal, K. (2006): Measuring landscapes: A planner's handbook. Washington, Island Press.

Breuste, J., Niemela, J., in Snep, R. P. H. (2008): Applying landscape ecological principles in urban environments. Landscape Ecology, 23(10), str. 1139-1142. DOI: 10.1007/s10980-008-9273-0

Broecker, W. (1975): Climatic change: Are we on the brink of a pronounced global warming? Science, 189, str. 460-463.

DOI: $10.1126 /$ science. 189.4201 .460

Bryan, B. A., Crossman, N. D., in King, D. (2008): Analyzing landscape futures for dry land agricultural areas: A case study in the Lower Murray region of southern Australia. V: Pettit, C., Cartwright, W., Bishop, I., Lowell, K., Pullar, D., in Duncan, D. (ur.): Landscape analysis and visualisation: Spatial models for natural resource management and planning, str. 407-434. New York, Springer. DOI: 10.1007/978-3-540-69168-6_20

Calthorpe, P. (2011): Urbanism in the age of climate change. Washington, Island Press. DOI: 10.5822/978-1-61091-005-7

Cartwright, A., Parnell, S., Oelofse, G., in Ward, S. (2012): Climate change at the city scale: Impacts, mitigation and adaptation in Cape Town. Oxfordshire, Routledge.

Cartwright, W. (2008): Visualizing alternative futures. V: Pettit, C., Cartwright, W., Bishop, I., Lowell, K., Pullar, D., in Duncan, D. (ur.): Landscape analysis and visualisation: Spatial models for natural resource management and planning, str. 489-507. New York, Springer.

DOI: 10.1007/978-3-540-69168-6_24

Chen, G. (2012): State rescaling, contested space, and inequality in the globalizing city-regions of China: Conceptual issues and empirical evidence. Urbani izziv, 23(supplement 2), str. S137-S149.

DOI: 10.5379/urbani-izziv-en-2012-23-supplement-2-012

Clarke, K. C. (2008): Mapping and modelling land use change: An application of the SLEUTH model. V: Pettit, C., Cartwright, W., Bishop, I., Lowell, K., Pullar, D., in Duncan, D. (ur.): Landscape analysis and visualisation: Spatial models for natural resource management and planning, str. 353-366. New York, Springer. DOI: 10.1007/978-3-540-69168-6_17

Condon, P., Cavens, D., in Miller, N. (2009): Urban planning tools for climate change mitigation. Cambridge, Lincoln Institute of Land Policy.

Corry, R. C., in Nassauer, J. I. (2005): Limitations of using landscape pattern indices to evaluate the ecological consequences of alternative plans and designs. Landscape and Urban Planning, 72(4), str. 265-280. DOI: 10.1016/j.landurbplan.2004.04.003
Costanza, R., in Voinov, A. (2004): Introduction: Spatially explicit landscape simulation models. V: Costanza, R., in Voinov, A. (ur.): Landscape simulation modeling: A spatially-explicit, dynamic approach, str. 3-20. New York, Springer. DOI: 10.1007/0-387-21555-7_1

Crichton, D., Nicol, F., in Roaf, S. (2009): Adapting buildings and cities for climate change. Oxford, Elsevier Ltd.

Dale, V., Brown, S., Haeuber, R., Hobbs, N., Huntly, N., Naiman, R., idr. (2000): Ecological Society of America report: Ecological principles and guidelines for managing the use of land. Ecological Applications, 10(3), str. 639-670.

Deming, M. E., in Swaffield, S. (2011): Landscape architecture research: Inquiry, strategy, design. Hoboken, NJ, John Wiley and Sons.

Deng, X., Su, H., in Zhan, J. (2008): Integration of multiple data sources to simulate the dynamics of land systems. Sensors, 8(2), str. 620-634.

Dockerty, T., Lovett, A., Appleton, K., Bone, A., in Sünnenberg, G. (2006): Developing scenarios and visualisations to illustrate potential policy and climatic influences on future agricultural landscapes. Agriculture, Ecosystems \& Environment, 114(1) str. 103-120. DOI: 10.1016/j.agee.2005.11.008

Dramstad, W. E., Olson, J. D., in Forman, R. T. T. (1996): Landscape ecology principles in landscape architecture and land-use planning. Cambridge, MA, Harvard University Graduate School of Design and Island Press.

Fabos, J. G. (1985): Land-use planning: From global to local challenge. New York, Chapman \& Hall.

Ferraz, S. F. B, Vettorazzi, C. A., Theobald, D. M., in Ballester, M. V. R. (2005): Landscape dynamics of Amazonian deforestation between 1984 and 2002 in central Rondônia, Brazil: Assessment and future scenarios. Forest Ecology and Management, 204(1), str. 69-85. DOI: 10.1016/j.foreco.2004.07.073

Flick, U. (1998): An introduction to qualitative research. London, Sage Publications.

Forman, R. T. T. (1995): Land mosaics: The ecology of landscapes and regions. Cambridge, Cambridge University Press.

Freemark, K., Hummon, C., White, D., in Hulse, D. (1996): Modeling risks to biodiversity in past, present and future landscapes. Ottawa, Canadian Wildlife Service Headquarters.

Greeuw, S., van Asselt, M., Grosskurth, J., Storms, C., Rijkens-Klomp, M. Rothman, D., idr. (2000): Cloudy crystal balls: An assessment of recent European and global scenario studies and models. Kopenhagen, European Environment Agency.

Guest, G., Bunce, A., in Johnson, L. (2006): How many interviews are enough? An experiment with data saturation and variability. Field Methods, 18(1), str. 59-82. DOI: 10.1177/1525822X05279903

Hamin, E. M., in Gurran, N. (2009): Urban form and climate change: Balancing adaptation and mitigation in the U.S. and Australia. Habitat International, 33(3), str. 238-245. DOI: 10.1016/j.habitatint.2008.10.005

Harms, B. H., Knaapen, J. P., in Rademakers, J. G. (1993): Landscape planning for nature restoration: Comparing regional scenarios. V: Vos, C. C., in Opdam, P. (ur.): Landscape ecology of a stressed environment, str. 197-218. London, Chapman \& Hall.

DOI: 10.1007/978-94-011-2318-1 9

Hodson, M., in Marvin, S. (2010): World cities and climate change: Producing urban ecological security. Berkshire, Open University Press.

Hulse, D., Branscomb, A., Enright, C., in Bolte, J. (2009): Anticipating floodplain trajectories: A comparison of two alternative futures approaches. Landscape Ecology, 24(8), str. 1067-1090.

DOI: $10.1007 /$ s10980-008-9255-2 
Hulse, D. W., Branscomb, A., in Payne, S. (2004): Envisioning alternative futures: Using citizen guidance to map future land and water use. Ecological Applications, 14(2), str. 325-341. DOI: 10.1890/02-5260

Hulse, D. W., Eilers, J., Freemark, K., White, D., in Hummon, C. (2000): Planning alternative future landscapes in Oregon: Evaluating effects on water quality and biodiversity. Landscape Journal, 19(1-2), str. 1-19.

Hulse, D., Goorjian, L., Richey, D., Flaxman, M., Hummon, C., White, D., idr. (1997): Possible futures for the Muddy Creek Watershed, Benton County. Eugene, The University of Oregon.

Hunter, L. M., Gonzalez, M. J., Stevenson, M., Karish, K. S., Toth, R., Edwards, T. C., idr. (2003): Population and land use change in the California Mojave: Natural habitat implications of alternative futures. Population Research and Policy Review, 22(4), str. 373-397. DOI: 10.1023/A:1027311225410

Hwang, C. L., in Yoon, K. (1981): Multiple attribute decision making: A state of the art survey. New York, Springer. DOI: 10.1007/978-3-642-48318-9

Inštitut za okoljsko pravo (2003): Conservation thresholds for land use planners. Washington.

Jenerette, G. D., in Potere, D. (2010): Global analysis and simulation of land-use change associated with urbanisation. Landscape Ecology, 25(5), str. 657-670. DOI: 10.1007/s10980-010-9457-2

Jenerette, G. D., in Wu, J. (2001): Analysis and simulation of land-use change in the central Arizona-Phoenix region, USA. Landscape Ecology, 16(7), str. 611-626. DOI: 10.1023/A:1013170528551

Jongman, R. H. G. (2002): Homogenisation and fragmentation of the European landscapes: Ecological consequences and solutions. Landscape and Urban Planning, 58(2-4), str. 211-221.

DOI: 10.1016/S0169-2046(01)00222-5

Karvonen, L. (2000): Guidelines for ecological landscape planning. Vantaa, Metsähallitus.

Kepner, W. G., Hernandez, M., Semmens, D. J., in Goodrich, D. (2008): The use of scenario analysis to assess future landscape change on a watershed condition in the Pacific Northwest (USA). V: Petrosillo, l., Müller, F., Jones, K. B., Zurlini, G., Krauze, K., Victorov, S., idr. (ur.): Use of landscape sciences for the assessment of environmental security, str. 237-261. Amsterdam, Springer.

Kosow, H., in Gabner, R. (2008): Methods of future and scenario analysis. Bonn, German Development Institute.

Kupfer, J. A. (2006): National assessments of forest fragmentation in the US. Global Environmental Change, 16(1), str. 73-82.

DOI: 10.1016/j.gloenvcha.2005.10.003

Landis, J. (1995): Imagining land use futures: Applying the California Urban Futures model. Journal of the American Planning Association, 61(4), str. 438-456. DOI: 10.1080/01944369508975656

Lee, T. (2014): Global cities and climate change: The trans-local relations of environmental governance. Oxfordshire, Routledge.

Lilieholm, R. J., Toth, R., in Edwards, T. C. (2005): Alternative future growth scenarios for Utah's Wasatch Front: identifying future conflicts between development and the protection of environmental quality and public health. Ecology and the Environment, 84, str. 1079-1088.

Linstone, H. A., in Turoff, M. (2002): The Delphi method: Techniques and applications. Boston, Addison-Wesley Publishing Company.

Liu, Y. (2009): Modelling urban development with geographical information systems and cellular automata. New York, Taylor \& Francis.

Mansergh, I., Lau, A., in Anderson, R. (2008): Geographic landscape visualisation in planning adaptation to climate change in Victoria, Austra- lia. V: Pettit, C., Cartwright, W., Bishop, I., Lowell, K., Pullar, D., in Duncan, D. (ur.): Landscape analysis and visualisation: Spatial models for natural resource management and planning, str. 469-487. New York, Springer. DOI: 10.1007/978-3-540-69168-6_23

Maxwell, T., Voinov, A., in Costanza, R. (2004): Spatial Simulation Using the SME. V: Costanza, R., in Voinov, A. (ur.): Landscape simulation modeling: A spatially-explicit, dynamic approach, str. 21-42. New York, Springer. DOI: 10.1007/0-387-21555-7_2

McHarg, I. (1969): Design with nature. Washington, Island Press.

Meadows, D. H., Meadows, D. L., Randers, J., in Behrens, W. W. (1972): The limits to growth. New York, Universe Books.

Mehaffy, M. W., in Haas, T. (2012): Poststructuralist fiddling while the world burns: Exiting the self made crisis of "architectural culture". Urbani izziv, 23(1), str. 80-90. DOI: 10.5379/urbani-izziv-en-2012-23-01-001

Meyer, W., Bryan, B., Lyle, G., McLean, J., Moon, T., Siebentritt, M., idr. (2013): Adapted future landscapes from aspiration to implementation. Gold Coast, National Climate Change Adaptation Research Facility.

Morley, P., Trammell, E. J., Reeve, I., McNeill, J., Brunckhorst, D., in Bassett, S. (2012): Past, present and future landscapes: Understanding alternative futures for climate change adaptation of coastal settlements and communities. Gold Coast, National Climate Change Adaptation Research Facility.

Moser, S. C., in Boykoff, M. T. (2013): Successful adaptation to climate change: Linking science and policy in a rapidly changing world. Oxfordshire, Routledge.

Mouat, D. A., Bassett, S., in Lancaster, J. (2006): The use of alternative futures in a strategy to assess the likelihood of increased land degradation leading to increased subsequent political instability. V: Kepner, W. G., Rubio, J. L., Mouat, D. A., in Pedrazzini, F. (ur.): Desertification in the Mediterranean region: A security issue, str. 601-614. Amsterdam, Springer. DOI: 10.1007/1-4020-3760-0_28

Mulligan, G. F., in Crampton, J. P. (2005): Population growth in the world's largest cities. Cities, 22(5), str. 365-380. DOI: 10.1016/j.cities.2005.07.001

Nassauer, J. I., in Corry, R. C. (2004): Using normative scenarios in landscape ecology. Landscape Ecology, 19(4), str. 343-356. DOI: 10.1023/B:LAND.0000030666.55372.ae

Oana, P. L., Harutyun, S., Brendan, W., in Sheila, C. (2011): Scenarios and indicators supporting urban regional planning. Procedia Social and Behavioral Sciences, 21, str. 243-252. DOI: 10.1016/j.sbspro.2011.07.012

Obeng-Odoom, F. (2012): Political economic origins of Sekondi-Takoradi, West Africa's new oil city. Urbani izziv, 23(2), str. 121-130. DOI: 10.5379/urbani-izziv-en-2012-23-02-005

Odum, H. W. (1951): American sociology: The story of sociology in the United States through 1950. New York, Longmans, Green and Co.

Opdam, P., Luque, S., in Jones, K. B. (2009): Changing landscapes to accommodate for climate change impacts: A call for landscape ecology. Landscape Ecology, 24(6), str. 715-721. DOI: 10.1007/s10980-009-9377-1

Pan, Y., Yu, Z., Holst, J., in Doluschitz, R. (2014): Integrated assessment of cropping patterns under different policy scenarios in Quzhou County, North China Plain. Land Use Policy, 40, str. 131-139. DOI: 10.1016/j.landusepol.2013.11.015

Patel, M., Kok, K., in Rothman, D. S. (2007): Participatory scenario construction in land use analysis: An insight into the experiences created by stakeholder involvement in the northern Mediterranean. Land Use Policy, 24(3), str. 546-561. DOI: 10.1016/j.landusepol.2006.02.005 
Penteado, H. M. (2013): Assessing the effects of applying landscape ecological spatial concepts on future habitat quantity and quality in an urbanizing landscape. Landscape Ecology, 28(10), str. 1909-1921. DOI: $10.1007 /$ s10980-013-9940-7

Pettit, C. J., in Wyatt, R. (2009): A planning support system toolkit approach for formulating and evaluating land-use change scenarios. V: Geertman, S., in Stillwell, J. (ur.): Planning support systems best practice and new methods, str. 69-90. New York, Springer.

DOI: 10.1007/978-1-4020-8952-7_4

Pickett, S. T. A., Cadenasso, M. L., Grove, J. M., Nilon, C. H., Pouyat, R. V., in Zipperer, W. C., idr. (2001): Urban ecological systems: Linking terrestrial ecological, physical, and socioeconomic components of metropolitan areas. Annual Review Ecological System, 32, str. 127-157. DOI: 10.1146/annurev.ecolsys.32.081501.114012

Pimentel, D., in Pimentel, M. (2006): Global environmental resources versus world population growth. Ecological Economics, 59(2), str. 195198. DOI: 10.1016/j.ecolecon.2005.11.034

Pimerol, J. C., in Romerio, S. B. (2000): Multicriteria decision in management: Principles and practice. Boston, Kluwer Academic Publishers. DOI: 10.1007/978-1-4615-4459-3

Prutsch, A., Grothmann, T., McCallum, S., Schauser, I., in Swart, R. (2014): Climate change adaptation manual: Lessons learned from European and other industrialized countries. Oxfordshire, Routledge.

Reyes, E., Martin, J. F., White, M. L., Day, J. W., in Kemp, G. P. (2004): Habitat changes in the Mississippi delta: Future scenarios and alternatives. V: Costanza, R., in Voinov, A. (ur.): Landscape simulation modeling: A spatially-explicit, dynamic approach, str. 119-142. New York, Springer. DOI: 10.1007/0-387-21555-7_5

Rosenzweig, C., Solecki, W. D., Hammer, S. A., in Mehrotra, S. (2011): Climate change and cities: First assessment report of the urban climate change research network. New York, Cambridge University Press. DOI: $10.1017 /$ СBO9780511783142

Santelmann, M. V., White, D., Freemark, K., Nassauer, J. I., Eilers, J. M., Vache, K. B., idr. (2004): Assessing alternative futures for agriculture in lowa, USA. Landscape Ecology, 19(4), str. 357-374.

DOI: 10.1023/B:LAND.0000030459.43445.19

Schooenboom, I. J. (1995): Overview and state of the art of scenario studies for the rural environment. V: Schoute, J. F., Finke, P. A., Veeneklaas, F. R., in Wolfert, H. P. (ur.): Scenario studies for the rural environment, str. 15-24. Dordrecht, Kluwer Academic Publishers.

Schumaker, N., Ernst, T., White, D., Baker, J., in Haggerty, P. (2004): Projecting wildlife responses to alternative future landscapes in Oregon's Willamette Basin. Ecological Applications, 14(2), str. 381-400. DOI: 10.1890/02-5010

Sharma, T., Carmichael, J., in Klinkenberg, B. (2005): A spatially explicit modeling approach to explore scenarios of sustainable agriculture futures. Journal of the Indian Society of Remote Sensing, 33(2), str. 353-363. DOI: 10.1007/BF02990056

Sheikh-Goodarzi, M., Alizadeh-Shabani, A., Salman-Mahiny, A., in Feghhi, J. (2012): Investigation of urban growth impacts on suitability of conservational patches using a landscape ecological approach (Study Area: Korganroud Watershed). Journal of Applied Ecology (Isfahan University of Technology), 1(1), str. 30-43.

Shoyama, K., in Yamagata, Y. (2014): Predicting land-use change for biodiversity conservation and climate-change mitigation and its effect on ecosystem services in a watershed in Japan. Ecosystem Services, 8, str. 25-34. DOI: 10.1016/j.ecoser.2014.02.004
Sleeter, B. M., Sohl, T. L., Bouchard, M. A., Reker, R. R., Soulard, C. E., Acevedo, W., idr. (2012): Scenarios of land use and land cover change in the conterminous United States: Utilizing the special report on emission scenarios at ecoregional scales. Global Environmental Change, 22(4), str. 896-914. DOI: 10.1016/j.gloenvcha.2012.03.008

Soliva, R., Ronningen, K., Bella, I., Bezak, P., Cooper, T., Flo, B. E., idr. (2008): Envisioning upland futures: Stakeholder responses to scenarios for Europe's mountain landscapes. Journal of Rural Studies, 24(1), str. 56-71. DOI: 10.1016/j.jrurstud.2007.04.001

Steinitz, C., Anderson, R., Arias, H., Bassett, S., Flaxman, M., Goode, T., idr. (2003): Alternative futures for changing landscapes: The San Pedro River Basin in Arizona and Sonora. Washington, Island Press.

Steinitz, C., Binford, M., Cote, P., Edwards, T., Ervin, Jr. S., Forman, R. T. T., idr. (1996): Biodiversity and landscape planning: Alternative futures for the region of Camp Pendleton, California. Cambridge, MA, Harvard University, Graduate School of Design.

Sun, X. F., Yue, T. X., in Fan, Z. F. (2012): Scenarios of changes in the spatial pattern of land use in China. Procedia Environmental Sciences, 13, str. 590-597. DOI: 10.1016/j.proenv.2012.01.050

Theobald, D M., in Hobbs, N. T. (2002): A framework for evaluating land use planning alternatives: Protecting biodiversity on private land. Conservation Ecology, 6(1), str. 5.

Tomlinson, R. (1968): A geographic information system for regional planning. V: Stewart, G. A. (ur.) Land Evaluation, str. 200-210. Melbourne, Macmillan

Turner, M. G. (1989): Landscape ecology: The effect of pattern on process. Annual Review of Ecology and Systematics, 20, str. 97-171. DOI: 10.1146/annurev.es.20.110189.001131

Verburg, P. H., van Berkel, D., B., van Doorn, A. M., van Eupen, M., in van den Heiligenberg, H. A. R. M. (2010): Trajectories of land use change in Europe: A model-based exploration of rural futures. Landscape Ecology, 25(2), str. 217-232. DOI: 10.1007/s10980-009-9347-7

Wang, H., Li, X., Long, H., Qiao, Y., in Li, Y. (2011): Development and application of a simulation model for changes in land-use patterns under drought scenarios. Computers \& Geosciences, 37(7), str. 831-843. DOI: 10.1016/j.cageo.2010.11.014

Wang, X., in Hofe. R. V. (2007): Research methods in urban and regional planning. Beijing, Tsinghua University Press, in Berlin, Springer. DOI: $10.1007 / 978-3-540-49658-8$

Watson, D., in Adams, M. (2011): Design for flooding: Architecture, landscape, and urban design for resilience to climate change. Hoboken, $\mathrm{NJ}$, John Wiley and Sons.

White, D., Minotti, P., G., Braczak, M., J., Sifneos, J. C., Freemark, K. E., Santelmann, M. V., idr. (1997): Assessing risks to biodiversity from future landscape change. Conservation Biology, 11(2), str. 349-360. DOI: 10.1046/j.1523-1739.1997.95458.x

Wilson, E., in Piper, J. (2010): Spatial planning and climate change. Oxfordshire, Routledge.

Wilson, V. (1997): Focus groups: A useful qualitative method for educational research? British Educational Research Journal, 23(2), str. 209-224. DOI: 10.1080/0141192970230207

Zhang, J., Kotze, N., in Yu, M. (2012): Living in a changing Chinese urban landscape: The Dalian case study. Urbani izziv, 23(2), str. 93-102. DOI: 10.5379/urbani-izziv-en-2012-23-02-002 